\title{
Magma storage and plumbing of adakite-type post-ophiolite intrusions in the Sabzevar ophiolitic zone, northeast Iran
}

\author{
K. Jamshidi ${ }^{1,2}$, H. Ghasemi ${ }^{1}$, V. R. Troll ${ }^{2}$, M. Sadeghian ${ }^{1}$, and B. Dahren ${ }^{2}$ \\ ${ }^{1}$ Faculty of Earth Sciences, Shahrood University, Shahrood, Iran \\ ${ }^{2}$ Department of Earth Sciences, CEMPEG, Uppsala University, Uppsala, Sweden \\ Correspondence to: K. Jamshidi (kh.jamshidi@shahroodut.ac.ir) \\ Received: 24 July 2014 - Published in Solid Earth Discuss.: 8 August 2014 \\ Revised: 15 November 2014 - Accepted: 30 November 2014 - Published: 14 January 2015
}

\begin{abstract}
Subduction-related adakite-type intrusive rocks emplaced into the late Cretaceous-Paleocene Sabzevar ophiolite zone, northeast Iran, range from Mg-andesite to rhyodacite in composition. Here we investigate the magma supply system to these subvolcanic intrusive rocks by applying thermobarometric mineral and mineral-melt equilibrium models, including amphibole thermobarometry, plagioclasemelt thermobarometry and clinopyroxene-melt barometry. Based on the results of these thermobarometric models, plagioclase crystallized dominantly at pressures of $\sim 350(130$ to 468$) \mathrm{MPa}$, while amphiboles record both low pressures $(\sim 300 \mathrm{MPa})$ and very high pressures ( $>700 \mathrm{MPa})$ of crystallization. The latter is supported by the calculated pressures for clinopyroxene crystallization (550 to $730 \mathrm{MPa}$ ). The association of amphibole with clinopyroxene and no plagioclase in the most primitive samples (Mg-andesites) is consistent with amphibole fractionation from very hydrous magmas at deep crustal levels of the plumbing system, which may have been a key process in intensifying adakite-type affinities in this rock suite. Barometry, combined with frequent disequilibrium features such as oscillatory-zoned and sieve-textured plagioclase crystals with An-rich overgrowths in more evolved samples, implies that final magma differentiation occurred in an open upper crustal magma system that developed progressively stronger compositional modifications during high-level magma storage.
\end{abstract}

\section{Introduction}

The Sabzevar ophiolitic zone (SOZ) in northeast Iran is part of the eastern Tethyan ophiolite belt and represents a remnant of the Cretaceous Tethyan ocean lithosphere which was obducted from the late Cretaceous to the early Paleocene period (Shojaat et al., 2003). The ophiolite belt contains ultramafic rocks (harzburgite, dunite and lherzolite), small masses of gabbro and a thick sequence of submarine basaltic lavas (Shojaat et al., 2003; Khalatbari Jafari et al., 2013). The ophiolite is intruded by widespread subvolcanic stocks and dykes of intermediate to felsic compositions; hence, the main purpose of this study is to investigate the compositional spectrum and ascent history of these post-ophiolite subvolcanic rocks. Although the petrology and tectonomagmatic evolution of the Sabzevar ophiolite belt was investigated in a number of studies previously (Lensch et al., 1977, 1980; Noghreyan, 1982; Majidi, 1999; Shojaat et al., 2003; Khalatbari Jafari et al., 2013; Shafaii Moghadam et al., 2013, etc.), a detailed evolutionary history of the post-ophiolite subvolcanic rocks has not yet been thoroughly investigated. The exceptions include a number of studies such as Spies et al. (1983), who reported on the volcanic rocks in the region between Sabzevar and Quchan (north Iran) and highlighted the presence of subalkaline rocks that range from $41 \pm 2.1$ to $2.7 \pm 0.2 \mathrm{Ma}$ in age, which become younger northward, reaching Late Miocene to Late Pliocene ages in the Quchan. Ghasemi et al. (2010) and Shabanian et al. (2012), working on Sarakhor adakitic domes (south of Quchan), suggested post-collisional melting of an oceanic slab and/or the mafic lower crust as a source for the post-ophiolite intrusive suite, possibly triggered by an asthenospheric rise after 
slab break-off. Mohamadi Gorani et al. (2013) suggested adakitic signatures of some felsic domes in the southwestern part of the Sabzevar ophiolite belt and attributed their origin to partial melting of the subducted oceanic slab. Jamshidi et al. (2014), studying the same subvolcanic domes in the north and northwest of the Sabzevar zone, interpreted this adakite magmatism as partial melts derived from a garnetamphibolite/eclogite source that originated from a metamorphism of the Sabzevar Neotethyan subducted oceanic slab underneath the southern edge of the eastern Alborz zone. The ascending magma was then subjected to magma chamber differentiation processes, such as assimilation and fractional crystallization during ascent, and eventual emplacement into the ophiolitic belt (Jamshidi et al., 2014). Rossetti et al. (2014) reported similar low-Mg\# adakite intrusive rocks in the Soltanabad area (northeast of the Sabzevar zone) and suggest that these rocks formed from high-pressure wet melting of an amphibolite source derived from the subducted oceanic slab and later amphibole fractionation.

Here, we present new major and trace element data on whole rocks plus major element data from the main mineral phases from intrusive rocks in the northern and southern Sabzevar belt to improve our knowledge on the history of the post-ophiolite intrusive activity in the wider region of the Sabzevar ophiolite complex. We attempt to compare postophiolite felsic rocks in the southern Sabzevar belt with dominantly intermediate ones in the north and aim to test if differences between the post-ophiolite subvolcanic rocks of the two sectors exist. Finally, we hope to establish the pressuretemperature conditions of amphibole and plagioclase crystallization through mineral-melt equilibrium thermobarometry to help reconstruct the former plumbing system to these rocks.

Amphibole occurs as an essential rock forming mineral in a wide variety of igneous and metamorphic rocks and is especially abundant in calc-alkaline igneous rocks. Experimental studies have synthesized amphibole over a pressure range of up to $2300 \mathrm{MPa}$ and $400^{\circ}$ to $1150^{\circ} \mathrm{C}$ in calc-alkaline compositions (Blundy and Holland, 1990); amphibole has therefore considerable potential as an indicator of crystallization conditions, both as geothermometer and geobarometer (Blundy and Holland, 1990; Ridolfi, 2010).

The composition and growth morphology of igneous feldspar usually reflect progressive changes in crystallization conditions, which give a reliable record of the crystallization dynamics of an associated melt and its thermal and compositional history (e.g., Troll and Schmincke, 2002; Slaby and Götze, 2004). In the studied rocks, amphibole and plagioclase are found most widely in the northern suite of intermediate rocks, and we employed the thermobarometers of Ridolfi and Renzulli (2012) for selected amphiboles to determine crystallization and storage conditions for these rocks. Plagioclase-liquid thermobarometry (Putirka, 2008) and clinopyroxene-melt barometry (Putirka, 2008) were em- ployed in order to complement and test the results from amphibole thermobarometry.

\section{Geological setting}

The late Mesozoic northward motion of the Arabian plate towards Eurasia at a rate of $26 \pm 2 \mathrm{~mm} \mathrm{yr}^{-1}$ at $\sim 59^{\circ} \mathrm{E}$ (Vernant et al., 2004) is associated with the subduction of the Neotethyan ocean under the central Iranian Plateau, which has resulted in various styles of deformation in different parts of the collision zone (Motaghi et al., 2012; Shabanian et al., 2012). The ongoing deformation is concentrated in the Zagros, Alborz and Kopeh Dagh Mountains, and in shear zones surrounding the central Iranian microcontinent (Agard et al. 2011; Motaghi et al. 2012). Neotethyan subduction gave rise to the Jurassic-Cretaceous Sanandaj-Sirjan subduction zone, trending parallel to the main Zagros thrust, as well as several back-arc oceanic seaways in central Iran (Omrani et al., 2008; Shafaii Moghadam et al., 2009; Rossetti et al., 2010). These back-arc oceanic domains (Sabzevar, Nain-Baft and Sistan) are thought to have opened during the Cretaceous period and closed during the transition from Paleocene to Eocene (Baroz et al., 1983; Arvin and Robinson, 1994; Shojaat et al., 2003; Babazadeh and de Wever, 2004). Iranian ophiolites as part of the Neotethyan oceanic region are the results of obduction processes of these minor oceanic seaways, showing discontinuous back-arc oceanic crust emplacement (Agard et al., 2011 and references therein).

The northeastern part of the Arabia-Eurasia collision zone lies in NE Iran, where the dismembered Sabzevar ophiolite complex, a $\sim 200 \mathrm{~km}$ long and $\sim 10 \mathrm{~km}$ wide belt, is located along the northern boundary of the central Iranian microcontinent (Shojaat et al., 2003). Plate tectonic reconstructions suggest that the Sabzevar ophiolite was part of the Tethyan Ocean that formed during Cretaceous rifting from a narrow but deep seaway, separating the central Iranian microcontinent from the Eurasian plate. The ophiolite was emplaced during an episode of northeast dipping subduction (i.e., closure) of the Tethyan seaway (the Sabzevar Ocean) in Upper Cretaceous/early Paleocene time (Shojaat et al., 2003). The emplacement of the Sabzevar ophiolitic belt was followed by lasting post-ophiolite volcanism from at least the Eocene $(\sim 40 \mathrm{Ma})$ to the end of the Pliocene $(\sim 2.3 \mathrm{Ma})$ (Lensch et al., 1977; Spies et al., 1983; Shojaat et al., 2003). This Eocene volcanism is expressed in central and in northern Iran (Berberian and King, 1981; Berberian et al., 1982; Bina et al., 1986; Stampfli and Borel, 2002; Agard et al., 2005; Shabanian et.al, 2012), and Eocene volcano-sedimentary rocks cover extensive areas in the Sabzevar region. Since the Oligocene, volcanism has been intermittent (Jahangiri, 2007) and focussed predominantly on the Turkish-Iranian plateau for $\sim 10 \mathrm{Ma}$ (e.g., Berberian and Berberian, 1981; Keskin et al., 1998; Azizi and Moinevaziri, 2009). The Oligo-Miocene sedimentary rocks are composed of marine flysch-type facies 
Table 1. Major and trace element contents of representative post-ophiolite subvolcanic samples of in northeast Iran.

\begin{tabular}{|c|c|c|c|c|c|c|c|c|c|c|c|c|c|c|c|c|}
\hline Samples & $\mathrm{N}-1$ & $\mathrm{~N}-2$ & $\mathrm{~N}-3$ & $\mathrm{~N}-4$ & N-5 & N-6 & N-7 & $\mathrm{N}-8$ & N-9 & N-10 & $\mathrm{N}-11$ & $\mathrm{~N}-12$ & $\mathrm{~N}-13$ & $\mathrm{~N}-14$ & N-15 & $\mathrm{N}-16$ \\
\hline $\mathrm{SiO}_{2}$ & 55.01 & 57.35 & 57.42 & 58.28 & 58.29 & 58.74 & 58.74 & 55.53 & 56.86 & 58.81 & 58.97 & 59.49 & 59.28 & 60.10 & 60.41 & 62.56 \\
\hline $\mathrm{TiO}_{2}$ & 0.68 & 0.58 & 0.52 & 0.48 & 0.53 & 0.71 & 0.56 & 0.70 & 0.64 & 0.66 & 0.44 & 0.59 & 0.43 & 0.50 & 0.45 & 0.48 \\
\hline $\mathrm{Al}_{2} \mathrm{O}_{3}$ & 17.25 & 14.25 & 18.06 & 17.08 & 15.03 & 16.70 & 18.59 & 18.24 & 18.22 & 16.75 & 17.27 & 15.20 & 15.59 & 19.07 & 17.82 & 17.74 \\
\hline $\mathrm{FeO}$ & 4.30 & 3.37 & 2.44 & 2.57 & 1.94 & 1.97 & 2.19 & 3.03 & 2.69 & 2.78 & 3.11 & 2.70 & 2.24 & 1.68 & 1.52 & 1.78 \\
\hline $\mathrm{Fe}_{2} \mathrm{O}_{3}$ & 2.87 & 3.37 & 4.53 & 2.57 & 1.94 & 1.97 & 4.06 & 4.55 & 4.03 & 1.85 & 2.07 & 2.70 & 1.49 & 3.12 & 2.28 & 2.68 \\
\hline $\mathrm{MnO}$ & 0.14 & 0.13 & 0.13 & 0.15 & 0.18 & 0.21 & 0.12 & 0.11 & 0.11 & 0.24 & 0.16 & 0.13 & 0.17 & 0.04 & 0.06 & 0.09 \\
\hline $\mathrm{MgO}$ & 4.23 & 6.03 & 3.91 & 3.25 & 2.83 & 3.82 & 2.61 & 4.98 & 4.38 & 2.76 & 1.86 & 3.74 & 4.56 & 2.06 & 4.62 & 3.06 \\
\hline $\mathrm{CaO}$ & 5.21 & 5.38 & 7.06 & 3.96 & 3.51 & 1.50 & 6.44 & 4.31 & 4.40 & 5.25 & 5.63 & 3.08 & 4.59 & 5.21 & 4.12 & 5.41 \\
\hline $\mathrm{Na}_{2} \mathrm{O}$ & 5.27 & 5.26 & 3.91 & 5.42 & 4.80 & 5.47 & 4.06 & 6.05 & 6.68 & 4.15 & 4.13 & 6.97 & 4.38 & 3.98 & 4.93 & 4.39 \\
\hline $\mathrm{K}_{2} \mathrm{O}$ & 1.15 & 2.95 & 1.28 & 1.74 & 2.50 & 1.75 & 0.59 & 1.23 & 1.10 & 1.25 & 0.63 & 1.02 & 1.59 & 1.73 & 1.87 & 0.72 \\
\hline $\mathrm{P}_{2} \mathrm{O}_{5}$ & 0.13 & 0.11 & 0.19 & 0.11 & 0.06 & 0.07 & 0.16 & 0.11 & 0.15 & 0.18 & 0.10 & 0.10 & 0.07 & 0.18 & 0.15 & 0.11 \\
\hline L.O.I. & 1.8 & 0.5 & 2.10 & 2.1 & 4.2 & 3.5 & 3.30 & 2.70 & 2.10 & 2.6 & 2.8 & 2.1 & 2.7 & 3.70 & 3.10 & 2.40 \\
\hline Sum & 99.87 & 99.85 & 101.5 & 99.89 & 99.93 & 101.43 & 99.89 & 101.63 & 101.33 & 99.89 & 99.93 & 99.90 & 99.93 & 101.35 & 101.91 & 101.41 \\
\hline $\mathrm{Ba}$ & 122 & 96 & 357.7 & 143 & 288 & 470 & 130.1 & 135.7 & 149.7 & 238 & 153 & 102 & 270 & 206.0 & 381.0 & 130.3 \\
\hline Co & 44.3 & 54.3 & 21.90 & 35.6 & 28.6 & 30.5 & 13.10 & 24.80 & 21.00 & 46.7 & 27.4 & 18.9 & 44.2 & 8.70 & 15.60 & 13.50 \\
\hline Cs & 0.1 & 0.1 & 0.60 & 0.5 & 1.4 & 1.4 & 0.40 & 1.00 & 0.10 & 1.6 & 0.2 & 0.2 & 0.6 & 0.50 & 0.60 & 0.20 \\
\hline $\mathrm{Ga}$ & 16.82 & 12.69 & 17.40 & 16.8 & 14.02 & 16.41 & 17.70 & 16.40 & 17.50 & 16.72 & 16.85 & 14.67 & 15.82 & 16.30 & 15.80 & 15.90 \\
\hline $\mathrm{Hf}$ & 1.8 & 1.62 & 2.00 & 0.94 & 1.22 & 1.49 & 2.20 & 2.10 & 2.20 & 2.89 & 1.18 & 2.41 & 1.11 & 2.70 & 2.90 & 2.40 \\
\hline $\mathrm{Nb}$ & 5 & 5 & 2.00 & 5 & 5 & 8 & 2.70 & 1.70 & 1.90 & 8 & 5 & 5 & 5 & 4.10 & 4.80 & 2.40 \\
\hline $\mathrm{Rb}$ & 4 & 12.4 & 19.80 & 12.7 & 39.1 & 18.5 & 9.20 & 22.60 & 10.20 & 17.6 & 3.1 & 5.7 & 7.7 & 22.40 & 31.80 & 10.10 \\
\hline $\mathrm{Sr}$ & 390 & 64 & 780.6 & 350 & 403 & 465 & 366.1 & 463.9 & 208.6 & 476 & 407 & 138 & 783 & 470.0 & 731.7 & 507.1 \\
\hline $\mathrm{Ta}$ & 0.2 & 0.3 & 0.10 & 0.3 & 0.4 & 0.6 & 0.20 & 0.10 & 0.20 & 0.5 & 0.3 & 0.2 & 0.5 & 0.30 & 0.40 & 0.10 \\
\hline Th & 0.5 & 0.6 & 2.50 & 0.3 & 1.6 & 1.2 & 1.30 & 1.10 & 0.90 & 2.2 & 0.5 & 0.8 & 1.2 & 1.50 & 3.00 & 0.80 \\
\hline $\mathrm{U}$ & 0.2 & 0.1 & 0.80 & 0.1 & 0.5 & 0.6 & 0.40 & 0.30 & 0.40 & 0.8 & 0.1 & 0.3 & 0.3 & 0.50 & 1.20 & 0.40 \\
\hline V & 176 & 167 & 208.00 & 111 & 76 & 80 & 134.00 & 207.00 & 170.00 & 117 & 87 & 119 & 82 & 70.00 & 76.00 & 86.00 \\
\hline $\mathrm{Zr}$ & 81 & 66 & 69.20 & 87 & 109 & 124 & 72.60 & 64.60 & 66.60 & 132 & 87 & 93 & 110 & 110.60 & 103.30 & 85.70 \\
\hline Y & 17 & 14 & 11.70 & 14 & 10 & 11 & 14.60 & 17.30 & 17.10 & 14 & 14 & 19 & 8 & 14.50 & 8.70 & 16.80 \\
\hline $\mathrm{La}$ & 3.3 & 4.7 & 10.90 & 3.7 & 6 & 5.8 & 7.50 & 5.80 & 5.60 & 7.8 & 5 & 4.3 & 7.3 & 8.80 & 11.90 & 6.10 \\
\hline $\mathrm{Ce}$ & 9.13 & 11.31 & 23.40 & 9.97 & 14.03 & 14.18 & 17.20 & 13.10 & 13.00 & 18.36 & 11.46 & 11.1 & 16 & 21.40 & 22.20 & 15.80 \\
\hline $\operatorname{Pr}$ & 1.4 & 1.7 & 2.94 & 1.4 & 1.9 & 1.9 & 2.31 & 1.92 & 1.96 & 2.3 & 1.6 & 1.9 & 2 & 2.70 & 2.66 & 2.25 \\
\hline $\mathrm{Nd}$ & 6.2 & 7.5 & 12.70 & 6 & 7.2 & 7.4 & 10.70 & 9.60 & 9.30 & 8.3 & 7 & 7.1 & 7 & 10.90 & 10.60 & 10.30 \\
\hline $\mathrm{Sm}$ & 1.9 & 2.3 & 2.60 & 1.7 & 1.7 & 1.7 & 2.30 & 2.70 & 2.60 & 1.9 & 1.7 & 2.2 & 1.5 & 2.50 & 2.10 & 2.50 \\
\hline $\mathrm{Eu}$ & 0.8 & 0.8 & 0.79 & 0.7 & 0.5 & 0.6 & 0.72 & 0.77 & 0.80 & 0.6 & 0.6 & 0.8 & 0.4 & 0.79 & 0.59 & 0.72 \\
\hline $\mathrm{Gd}$ & 2.7 & 2.8 & 2.16 & 1.7 & 1.7 & 1.6 & 2.81 & 3.12 & 3.02 & 2.1 & 2 & 2.4 & 1.1 & 2.67 & 1.97 & 2.80 \\
\hline $\mathrm{Tb}$ & 0.4 & 0.4 & 0.38 & 0.3 & 0.3 & 0.2 & 0.45 & 0.55 & 0.52 & 0.4 & 0.3 & 0.5 & 0.3 & 0.43 & 0.30 & 0.49 \\
\hline Dy & 2.3 & 2.8 & 2.06 & 1.5 & 1.5 & 1.7 & 2.62 & 3.21 & 2.80 & 2.5 & 1.9 & 2.6 & 1.1 & 2.54 & 1.63 & 2.88 \\
\hline Но & 0.6 & 0.5 & 0.37 & 0.4 & 0.3 & 0.3 & 0.50 & 0.61 & 0.57 & 0.5 & 0.3 & 0.7 & 0.2 & 0.43 & 0.29 & 0.54 \\
\hline Er & 1.5 & 1.7 & 1.14 & 1 & 0.9 & 0.7 & 1.50 & 1.76 & 1.84 & 1.2 & 0.9 & 1.9 & 0.6 & 1.35 & 0.88 & 1.82 \\
\hline $\mathrm{Yb}$ & 1.3 & 1.6 & 1.10 & 0.9 & 0.8 & 0.7 & 1.54 & 1.67 & 1.73 & 1.3 & 0.9 & 2 & 0.6 & 1.35 & 0.84 & 1.67 \\
\hline $\mathrm{Lu}$ & 0.2 & 0.3 & 0.18 & 0.1 & 0.1 & 0.1 & 0.24 & 0.29 & 0.28 & 0.2 & 0.1 & 0.3 & 0.1 & 0.23 & 0.14 & 0.29 \\
\hline $\mathrm{Sr} / \mathrm{Y}$ & 22.94 & 4.57 & 66.71 & 25.00 & 40.30 & 42.27 & 25.07 & 26.81 & 12.19 & 34.00 & 29.07 & 7.26 & 97.88 & 32.41 & 84.10 & 30.1 \\
\hline $\mathrm{La} / \mathrm{Yb}$ & 2.54 & 2.94 & 9.91 & 4.11 & 7.50 & 8.29 & 4.87 & 3.47 & 3.24 & 6.00 & 5.56 & 2.15 & 12.17 & 6.52 & 14.17 & 3.65 \\
\hline $\mathrm{Zr} / \mathrm{Sm}$ & 42.63 & 28.70 & 4.05 & 51.18 & 64.12 & 72.94 & 5.70 & 5.82 & 6.43 & 69.47 & 51.18 & 42.27 & 73.33 & 9.48 & 8.69 & 7.27 \\
\hline Mg\# & 50 & 59.3 & 61.6 & 56 & 67.1 & 66 & 54.4 & 62.2 & 62 & 50 & 37.4 & 58.1 & 67.1 & 55.1 & 75.2 & 63.2 \\
\hline $\mathrm{Eu} / \mathrm{Eu}^{*}$ & 1.1 & 1 & 1 & 1.2 & 0.9 & 1 & 0.9 & 0.8 & 0.9 & 0.9 & 1 & 1.1 & 1 & 0.9 & 0.9 & 0.8 \\
\hline $\mathrm{A} / \mathrm{CNK}$ & 0.8 & 0.6 & 0.8 & 0.9 & 0.8 & 1.2 & 0.9 & 0.9 & 0.9 & 1 & 0.9 & 0.8 & 0.8 & 1.1 & 1 & 1 \\
\hline
\end{tabular}

in their lower parts, while younger facies are of continental origin and contain, in some parts, extremely high percentages of volcanic detritus. These sedimentary rocks are tectonically imbricated, often steeply dipping and penetrated by Oligocene alkali-olivine-basalt magmatism (Ghasemi et al., 2011). Following the Eocene volcanic and volcanosedimentary and the Oligocene volcanic activity, magmatism recommenced in the region and continued until the end of the Pliocene. In the Sabzevar belt, characteristically, post-ophiolite subvolcanic rocks occur in the north and in the south of the ophiolite zone (Fig. 1), with magmatismcomprised intermediate rocks in the northern part and felsic rocks dominating the southern part (Fig. 2). Fragments of host rocks, including serpentinized harzburgites and tuffa- ceous siltstone, are found in some intrusions as xenoliths (Fig. 3a, b). Large volumes of detritus originated from these intrusive domes, forming Pliocene-Pleistocene conglomerates (Fig. 3c). According to these geological lines of evidence and stratigraphic relationships, Salehinejad (2008) and Jamshidi et al. (2014) suggested that the studied domes eventually outcropped at the Earth's surface around the Miocene-Pliocene boundary. Recent integrated U-Pb zircon and ${ }^{40} \mathrm{Ar} /{ }^{39} \mathrm{Ar}$ white mica and amphibole geochronology on similar rock suites in the Soltanabad region by Rossetti et al. (2014) constrains the Sabzevar magmatism to the late Paleocene (at ca. $58 \mathrm{Ma}$ ). In the absence of a comprehensive dating study, we cannot specify the age of our post-ophiolite rocks; however, we note that the presence of xenoliths that 
Table 1. Continued.

\begin{tabular}{|c|c|c|c|c|c|c|c|c|c|c|c|c|c|c|c|c|}
\hline Samples & $\mathrm{N}-17$ & N-18 & $\mathrm{N}-19$ & $\mathrm{~N}-20$ & $\mathrm{~N}-21$ & $\mathrm{~N}-22$ & $\mathrm{~N}-23$ & S-24 & S-25 & S-26 & S-27 & S-28 & S-29 & S-30 & S-31 & S-32 \\
\hline $\mathrm{SiO}_{2}$ & 60.07 & 62.31 & 64.09 & 62.78 & 68.61 & 63.60 & 63.71 & 69.72 & 70.23 & 70.28 & 70.40 & 70.72 & 70.78 & 70.95 & 71.27 & 70.78 \\
\hline $\mathrm{TiO}_{2}$ & 0.48 & 0.42 & 0.32 & 0.41 & 0.15 & 0.47 & 0.31 & 0.02 & 0.04 & 0.10 & 0.04 & 0.07 & 0.07 & 0.08 & 0.07 & 0.08 \\
\hline $\mathrm{Al}_{2} \mathrm{O}_{3}$ & 17.13 & 15.51 & 17.04 & 18.31 & 18.82 & 17.29 & 16.78 & 20.64 & 20.24 & 18.73 & 19.81 & 18.67 & 16.60 & 18.2 & 17.14 & 15.44 \\
\hline $\mathrm{FeO}$ & 2.43 & 2.33 & 1.53 & 1.63 & 0.81 & 1.80 & 1.88 & 0.25 & 0.30 & 0.51 & 0.28 & 0.41 & 0.36 & 0.44 & 0.42 & 0.40 \\
\hline $\mathrm{Fe}_{2} \mathrm{O}_{3}$ & 1.62 & 1.55 & 1.53 & 1.63 & 0.81 & 2.70 & 1.25 & 0.25 & 0.30 & 0.51 & 0.28 & 0.41 & 0.36 & 0.44 & 0.24 & 0.49 \\
\hline $\mathrm{MnO}$ & 0.22 & 0.12 & 0.20 & 0.05 & 0.08 & 0.08 & 0.15 & 0.06 & 0.04 & 0.04 & 0.04 & 0.03 & 0.06 & 0.04 & 0.05 & 0.05 \\
\hline $\mathrm{MgO}$ & 2.17 & 2.96 & 1.17 & 2.45 & 0.75 & 2.92 & 2.10 & 0.10 & 0.18 & 0.25 & 0.16 & 0.24 & 0.22 & 0.23 & 0.43 & 0.25 \\
\hline $\mathrm{CaO}$ & 4.38 & 4.26 & 3.31 & 3.62 & 0.87 & 5.25 & 4.59 & 1.25 & 0.46 & 1.97 & 0.42 & 0.81 & 2.68 & 1.81 & 0.35 & 1.75 \\
\hline $\mathrm{Na}_{2} \mathrm{O}$ & 4.58 & 4.19 & 4.69 & 5.27 & 6.51 & 4.51 & 4.35 & 4.57 & 5.38 & 5.33 & 5.37 & 5.73 & 4.85 & 5.26 & 6.32 & 5.13 \\
\hline $\mathrm{K}_{2} \mathrm{O}$ & 1.54 & 1.35 & 2.13 & 2.05 & 2.24 & 0.77 & 1.11 & 3.57 & 3.62 & 2.90 & 3.48 & 3.35 & 1.92 & 2.67 & 3.46 & 2.62 \\
\hline $\mathrm{P}_{2} \mathrm{O}_{5}$ & 0.06 & 0.08 & 0.09 & 0.22 & 0.13 & 0.13 & 0.06 & 0.03 & 0.05 & 0.04 & 0.03 & 0.03 & 0.06 & 0.06 & 0.06 & 0.05 \\
\hline L.O.I. & 2.6 & 2.4 & 1.9 & 3.10 & 1.60 & 1.90 & 1.8 & 1.10 & 0.70 & 0.80 & 1.10 & 1.00 & 3.50 & 1.20 & 0.80 & 1.4 \\
\hline Total & 99.94 & 99.98 & 99.95 & 101.43 & 101.32 & 101.4 & 99.93 & 101.50 & 101.53 & 101.41 & 101.41 & 101.44 & 101.43 & 101.34 & 100.62 & 99.98 \\
\hline $\mathrm{Ba}$ & 272 & 181 & 300 & 445.6 & 463.9 & 132.5 & 323 & 518.0 & 545.1 & 481.0 & 559.6 & 539.2 & 318.5 & 413.4 & 424.3 & 408 \\
\hline $\mathrm{Co}$ & 22.2 & 49.5 & 26.6 & 9.30 & 1.20 & 13.60 & 31.8 & 2.00 & 2.00 & 2.00 & 1.00 & 2.00 & 1.00 & 1.00 & 1.00 & 36.9 \\
\hline $\mathrm{Cs}$ & 0.4 & 0.4 & 1 & 0.90 & 0.80 & 0.20 & 0.7 & $<0.5$ & 0.50 & 1.00 & $<0.5$ & 1.10 & 1.20 & 1.30 & 0.50 & 1.3 \\
\hline $\mathrm{Ga}$ & 15.97 & 16.28 & 15.36 & 16.80 & 17.70 & 15.80 & 15.71 & 2.60 & 1.80 & 0.80 & 1.80 & 17.40 & 17.20 & 17.80 & 16.50 & 17.98 \\
\hline Hf & 2.69 & 1.95 & 0.58 & 3.20 & 2.70 & 2.80 & 0.9 & 18.70 & 16.10 & 16.40 & 16.00 & 1.90 & 2.10 & 2.40 & 2.00 & 0.96 \\
\hline $\mathrm{Nb}$ & 9 & 8 & 15 & 5.80 & 7.70 & 2.60 & 5 & 2.10 & 1.90 & 2.00 & 1.90 & 5.20 & 5.40 & 5.00 & 5.20 & 5 \\
\hline $\mathrm{Rb}$ & 9.3 & 11.6 & 42.4 & 38.70 & 43.10 & 10.5 & 10.9 & 6.80 & 3.70 & 5.00 & 4.10 & 65.50 & 35.70 & 52.70 & 65.30 & 60 \\
\hline $\mathrm{Sr}$ & 550 & 283 & 358 & 848.5 & 673.5 & 400 & 670 & 70.10 & 73.60 & 58.00 & 68.30 & 811.00 & 512.2 & 810.6 & 208.2 & 774 \\
\hline $\mathrm{Ta}$ & 0.6 & 0.4 & 0.9 & 0.40 & 0.60 & 0.10 & 0.5 & 337.80 & 344.50 & 894.50 & 335.10 & 0.40 & 0.30 & 0.30 & 0.40 & 0.6 \\
\hline Th & 3.6 & 1.4 & 4.7 & 3.60 & 3.80 & 0.70 & 1.1 & 0.60 & 0.30 & 0.30 & 0.30 & 0.50 & 0.70 & 0.70 & 0.80 & 0.9 \\
\hline $\mathrm{U}$ & 0.9 & 0.5 & 1 & 1.20 & 1.20 & 0.40 & 0.2 & 1.60 & 1.70 & 1.50 & 1.50 & 1.10 & 0.70 & 1.10 & 1.30 & 0.8 \\
\hline V & 64 & 88 & 31 & 58.00 & 19.00 & 90.00 & 68 & 1.80 & 1.00 & 1.10 & 1.00 & 6.00 & 7.00 & 7.00 & 8.00 & 6 \\
\hline $\mathrm{Zr}$ & 160 & 92 & 186 & 124.30 & 90.10 & 88.00 & 71 & $<5$ & $<5$ & 9.00 & $<5$ & 46.40 & 50.0 & 53.8 & 49.0 & 59 \\
\hline $\mathrm{Y}$ & 12 & 10 & 15 & 9.20 & 9.20 & 17.00 & 5 & 38.40 & 40.50 & 61.40 & 38.80 & 2.90 & 2.70 & 3.20 & 2.70 & 3 \\
\hline $\mathrm{La}$ & 12.6 & 4.9 & 15.9 & 13.00 & 15.40 & 6.90 & 6.1 & 6.30 & 5.70 & 3.40 & 5.50 & 2.70 & 2.50 & 3.40 & 2.40 & 3.3 \\
\hline $\mathrm{Ce}$ & 26.61 & 11.37 & 35.1 & 26.40 & 31.50 & 16.30 & 12.27 & 3.80 & 5.50 & 5.10 & 5.90 & 4.70 & 4.60 & 6.80 & 4.50 & 7.05 \\
\hline $\operatorname{Pr}$ & 3 & 1.7 & 4 & 3.04 & 3.60 & 2.34 & 1.4 & 7.50 & 10.10 & 9.20 & 10.20 & 0.63 & 0.59 & 0.82 & 0.53 & 0.9 \\
\hline $\mathrm{Nd}$ & 10.9 & 6.2 & 13.6 & 11.10 & 12.90 & 10.10 & 5.9 & 0.93 & 1.21 & 1.14 & 1.29 & 2.70 & 2.20 & 3.20 & 2.10 & 3.3 \\
\hline $\mathrm{Sm}$ & 1.8 & 1.7 & 2.4 & 2.10 & 1.90 & 2.50 & 1.5 & 3.50 & 4.30 & 4.20 & 5.10 & 0.50 & 0.40 & 0.60 & 0.40 & 0.5 \\
\hline $\mathrm{Eu}$ & 0.7 & 0.6 & 0.6 & 0.61 & 0.55 & 0.69 & 0.4 & 0.80 & 1.00 & 0.80 & 1.00 & 0.14 & 0.16 & 0.18 & 0.16 & 0.2 \\
\hline Gd & 1.9 & 1.7 & 1.7 & 1.59 & 1.59 & 2.83 & 0.8 & 0.26 & 0.25 & 0.24 & 0.29 & 0.39 & 0.38 & 0.50 & 0.38 & 0.5 \\
\hline $\mathrm{Tb}$ & 0.3 & 0.3 & 0.4 & 0.27 & 0.26 & 0.48 & 0.1 & 1.02 & 0.96 & 0.61 & 0.97 & 0.08 & 0.07 & 0.09 & 0.08 & $<0.1$ \\
\hline Dy & 1.4 & 1.6 & 1.7 & 1.46 & 1.39 & 2.74 & 0.7 & 0.18 & 0.17 & 0.10 & 0.16 & 0.39 & 0.39 & 0.45 & 0.37 & 0.5 \\
\hline Ho & 0.4 & 0.4 & 0.4 & 0.29 & 0.26 & 0.59 & 0.1 & 0.96 & 0.77 & 0.54 & 0.91 & 0.08 & 0.07 & 0.09 & 0.08 & 0.1 \\
\hline $\mathrm{Er}$ & 1 & 1 & 0.9 & 0.86 & 0.78 & 1.70 & 0.4 & 0.18 & 0.16 & 0.10 & 0.16 & 0.21 & 0.22 & 0.27 & 0.20 & 0.2 \\
\hline $\mathrm{Yb}$ & 1.1 & 0.8 & 0.7 & 0.77 & 0.78 & 1.73 & 0.4 & 0.52 & 0.43 & 0.25 & 0.41 & 0.17 & 0.18 & 0.22 & 0.19 & 0.1 \\
\hline $\mathrm{Lu}$ & 0.2 & 0.1 & 0.1 & 0.14 & 0.13 & 0.30 & 0.1 & 0.47 & 0.38 & 0.26 & 0.42 & 0.03 & 0.03 & 0.03 & 0.03 & 0.1 \\
\hline $\mathrm{Sr} / \mathrm{Y}$ & 45.83 & 28.30 & 23.87 & 92.22 & 73.20 & 23.53 & 134.00 & 15.96 & 26.58 & 35.38 & 24.29 & 279.6 & 189.7 & 253.3 & 77.1 & 258 \\
\hline $\mathrm{La} / \mathrm{Yb}$ & 11.45 & 6.13 & 22.71 & 16.88 & 19.74 & 3.99 & 15.25 & 3.99 & 53.61 & 263.0 & 60.92 & 15.88 & 13.89 & 15.45 & 12.63 & 33 \\
\hline $\mathrm{Zr} / \mathrm{Sm}$ & 88.89 & 54.12 & 77.50 & 15.13 & 161.55 & 7.22 & 47.33 & 549.69 & 1086 & 130 & 1230 & 381 & 102 & 153.79 & 723.6 & 118 \\
\hline $\mathrm{Mg \#}$ & 47.2 & 56 & 43.4 & 60 & 48.1 & 62 & 52.8 & 28.6 & 37.5 & 33 & 36.4 & 37 & 37 & 34.3 & 50.6 & 38.2 \\
\hline $\mathrm{Eu} / \mathrm{Eu}^{*}$ & 1.1 & 1.1 & 0.9 & 1 & 1 & 0.8 & 1.1 & 0.9 & .0 .8 & 1.1 & 0.9 & 1 & 1.2 & 1 & 1.1 & 1.2 \\
\hline $\mathrm{A} / \mathrm{CNK}$ & 1 & 1 & 1 & 1 & 1.1 & 0.9 & 1.2 & 2.2 & 1.2 & 1.1 & 1.2 & 1.1 & 1.2 & 1 & 1.1 & 1 \\
\hline
\end{tabular}

look like Eocene tuffaceous siltstones and marls causes us to consider a post-Eocene age for at least some of the subvolcanic rocks in question.

\section{Method}

\subsection{Analytical techniques}

Twenty-three fresh whole rock samples from the northern sector and 34 samples from the southern sector were selected for major and trace element analysis at AMCE analytical laboratory, Vancouver, Canada. Total abundances of the major oxides were determined by ICP-emission spectrometry following a lithium metaborate/tetraborate fusion and dilute nitric digestion (analytical code: 4A04). Loss on ignition (LOI) is by weight difference after ignition at $1000^{\circ} \mathrm{C}$. $\mathrm{Fe}_{2} \mathrm{O}_{3}$ is reported as total. We recalculated $\mathrm{FeO}$ and $\mathrm{Fe}_{2} \mathrm{O}_{3}$ according to the method suggested in Le Maitre (1976). Trace elements and REE concentrations were obtained by solution inductively coupled plasma-mass spectrometry (ICP-MS, Analytical code: Group 1T) for whole rocks. For further analytical details and uncertainties please see www.acmelab.com. Major trace element data for 57 post-ophiolite subvolcanic rocks are listed in Table 1.

Major element analyses on selected minerals (amphibole, plagioclase and pyroxene) were performed on Jeol JXA 8530F Hyperpobe at CEMPEG. Analytical conditions included an accelerating voltage of $15 \mathrm{kV}$, a beam current of $10 \mathrm{nA}$ and counting times of $10 \mathrm{~s}$ on peaks and $5 \mathrm{~s}$ on \pm background. For calibration of all elements, a set of mineral and synthetic standards has been used. All elements were 
Table 1. Continued.

\begin{tabular}{|c|c|c|c|c|c|c|c|c|c|c|c|c|c|c|c|}
\hline Samples & S-33 & S-34 & S-35 & S-36 & S-37 & S-38 & S-39 & S- 40 & S-41 & S-42 & S-43 & S-44 & S-45 & S-46 & S-47 \\
\hline $\mathrm{SiO}_{2}$ & 71.39 & 71.17 & 71.59 & 72.30 & 72.59 & 73.22 & 72.09 & 72.30 & 72.32 & 72.46 & 72.54 & 72.64 & 72.92 & 73.14 & 73.62 \\
\hline $\mathrm{TiO}_{2}$ & 0.08 & 0.10 & 0.02 & 0.03 & 0.04 & 0.02 & 17.64 & 17.53 & 17.62 & 16.88 & 16.94 & 17.23 & 17.52 & 17.55 & 0.03 \\
\hline $\mathrm{Al}_{2} \mathrm{O}_{3}$ & 16.63 & 16.34 & 15.24 & 15.53 & 14.90 & 16.45 & 0.32 & 0.34 & 0.38 & 0.34 & 0.28 & 0.37 & 0.35 & 0.36 & 15.19 \\
\hline $\mathrm{Fe}_{2} \mathrm{O}_{3}$ & 0.66 & 0.50 & 0.40 & 0.44 & 0.42 & 0.39 & 0.12 & 0.18 & 0.24 & 0.13 & 0.14 & 0.18 & 0.16 & 0.16 & 0.31 \\
\hline $\mathrm{MnO}$ & 0.15 & 0.05 & 0.09 & 0.09 & 0.04 & 0.08 & 1.52 & 0.40 & 0.26 & 0.51 & 0.80 & 0.60 & 1.34 & 1.63 & 0.05 \\
\hline $\mathrm{MgO}$ & 0.53 & 0.26 & 0.20 & 0.25 & 0.21 & 0.13 & 5.12 & 6.50 & 7.07 & 5.57 & 5.27 & 6.22 & 5.58 & 5.17 & 0.15 \\
\hline $\mathrm{K}_{2} \mathrm{O}$ & 3.50 & 2.76 & 2.91 & 2.56 & 3.47 & 3.75 & 0.06 & 0.04 & 0.06 & 0.03 & 0.01 & 0.06 & 0.01 & 0.01 & 3.33 \\
\hline $\mathrm{P}_{2} \mathrm{O}_{5}$ & 0.17 & 0.05 & 0.08 & 0.07 & 0.05 & 0.05 & 0.06 & 0.03 & 0.03 & 0.06 & 0.09 & 0.03 & 0.07 & 0.06 & 0.04 \\
\hline L.O.I. & 1.40 & 0.4 & 1.4 & 0.9 & 1 & 0.80 & 0.90 & 0.70 & 0.60 & 1.00 & 1.50 & 0.60 & 0.80 & 0.70 & 0.3 \\
\hline Total & 101.42 & 99.97 & 99.96 & 99.98 & 99.98 & 101.53 & 101.63 & 101.50 & 101.61 & 101.52 & 101.42 & 101.55 & 101.41 & 101.45 & 99.97 \\
\hline $\mathrm{Ba}$ & 558.9 & 416 & 541 & 471 & 479 & 493.8 & 507.5 & 466.5 & 445.5 & 510.1 & 502.8 & 487.8 & 310.8 & 304 & 508 \\
\hline Cs & 1.30 & 0.4 & 0.9 & 0.6 & 2.3 & 3.20 & 2.50 & 0.70 & 0.50 & 1.30 & 2.00 & 1.20 & 1.20 & 1.70 & 2.2 \\
\hline $\mathrm{Ta}$ & 0.80 & 0.6 & 1 & 0.7 & 0.6 & 0.70 & 0.60 & 0.50 & 0.40 & 0.80 & 0.70 & 0.50 & 1.00 & 1.00 & 0.9 \\
\hline Th & 4.80 & 1 & 3.1 & 2.7 & 0.8 & 1.70 & 1.20 & 1.00 & 0.10 & 1.00 & 2.10 & 1.20 & 0.40 & 0.30 & 1.7 \\
\hline $\mathrm{U}$ & 2.60 & 0.7 & 1.5 & 1.3 & 1.3 & 1.90 & 1.40 & 1.70 & 1.10 & 2.40 & 2.00 & 1.50 & 1.90 & 1.70 & 1.7 \\
\hline V & 10.0 & 7 & 1 & 1 & 2 & $<5$ & $<5$ & 5.00 & $<5$ & $<5$ & $<5$ & $<5$ & $<5$ & $<5$ & 1 \\
\hline $\mathrm{Zr}$ & 74.0 & 67 & 52 & 45 & 41 & 39.50 & 41.1 & 43.9 & 31.60 & 39.4 & 41.9 & 43.70 & 24.80 & 24.70 & 42 \\
\hline $\mathrm{Y}$ & 13.1 & 3 & 7 & 7 & 5 & 3.60 & 5.60 & 4.70 & 2.20 & 3.40 & 6.40 & 4.30 & 4.80 & 4.90 & 5 \\
\hline $\mathrm{La}$ & 15.6 & 4.3 & 9.6 & 8.9 & 1.8 & 5.10 & 5.10 & 4.40 & 1.00 & 4.60 & 4.10 & 3.40 & 3.00 & 2.90 & 4.8 \\
\hline $\mathrm{Ce}$ & 30.8 & 9.12 & 20.09 & 17.59 & 4.07 & 9.90 & 10.0 & 7.10 & 1.40 & 9.00 & 7.90 & 6.90 & 4.70 & 5.30 & 9.53 \\
\hline $\operatorname{Pr}$ & 3.72 & 1 & 2.2 & 2 & 0.5 & 1.19 & 1.19 & 0.91 & 0.17 & 1.08 & 0.98 & 0.84 & 0.61 & 0.63 & 1.2 \\
\hline $\mathrm{Nd}$ & 13.4 & 3.7 & 8.4 & 7.2 & 1.9 & 5.00 & 4.70 & 3.60 & 0.70 & 4.10 & 3.30 & 3.60 & 2.50 & 2.50 & 4.6 \\
\hline $\mathrm{Sm}$ & 2.50 & 0.6 & 1.4 & 1.3 & 0.3 & 1.00 & 0.90 & 0.80 & 0.20 & 0.80 & 1.00 & 0.70 & 1.00 & 1.00 & 0.9 \\
\hline $\mathrm{Eu}$ & 0.42 & 0.2 & 0.4 & 0.3 & 0.2 & 0.24 & 0.24 & 0.27 & 0.13 & 0.24 & 0.23 & 0.26 & 0.30 & 0.32 & 0.2 \\
\hline $\mathrm{Gd}$ & 2.22 & 0.5 & 1.2 & 1.5 & 0.7 & 0.94 & 0.87 & 0.78 & 0.28 & 0.83 & 1.04 & 0.64 & 1.23 & 1.20 & 0.7 \\
\hline $\mathrm{Zr} / \mathrm{Sm}$ & 147.73 & 111.7 & 37.1 & 34.6 & 136.7 & 244.5 & 259.1 & 844.2 & 1137 & 673.1 & 498.2 & 510.1 & 263.30 & 212.31 & 46.67 \\
\hline Mg\# & 44.5 & 38.8 & 37.5 & 30.8 & 37.7 & 25 & 27.3 & 34.6 & 38.7 & 27.7 & 33.3 & 32.7 & 31.4 & 30.8 & 37.3 \\
\hline $\mathrm{Eu} / \mathrm{Eu}^{*}$ & 1.2 & 1.1 & 1 & 0.8 & 1.2 & 0.8 & 0.9 & 1.1 & 1.6 & 0.9 & 0.8 & 1.2 & 0.9 & 0.9 & 0.8 \\
\hline $\mathrm{A} / \mathrm{CNK}$ & 1 & 1 & 1 & 1.2 & 1.1 & 1.6 & 1.1 & 1.2 & 1 & 1.2 & 1.2 & 1.1 & 1.1 & 1.2 & 1.2 \\
\hline
\end{tabular}

analyzed using $K$ (alpha) lines. The analyzed data set consists of 197 points on amphibole, 212 on plagioclase and 29 on clinopyroxene, collected from 30 amphibole, 26 plagioclase and five complementary clinopyroxene crystals. Representative compositions of selected minerals are given in Tables 2,3 and 4.

\subsection{Amphibole thermobarometry}

Temperature, pressure, oxygen fugacity and $\mathrm{H}_{2} \mathrm{O}_{\text {melt }}$ conditions were estimated from amphibole compositions using the recent thermobarometric formulation of Ridolfi and Renzulli (2012), which is able to estimate the $P, T$ and $f \mathrm{O}_{2}$ in a wide range of amphibole crystallization conditions. Their new single-crystal model (requiring only the amphibole compositions) allows us to estimate the physico-chemical parameters at low uncertainties $\left(T \pm 23.5^{\circ} \mathrm{C}, P \pm 11.5 \%\right.$, $\mathrm{H}_{2} \mathrm{O}_{\text {melt }} \pm 0.78$ wt $\%$ ) for calc-alkaline and alkaline magmas up to $1130^{\circ} \mathrm{C}$ and $2200 \mathrm{MPa}$ and $\triangle \mathrm{NNO}$ values $( \pm 0.37 \mathrm{log}$ units) up to $500 \mathrm{MPa}$ ( $\mathrm{NNO}=$ nickel-nickel oxide buffers). Application of this method is limited to igneous amphibole phenocrysts and cannot be applied to fluid-related (hydrothermal) amphibole veins, to microlites or to quenched amphibole zones in erupted products that likely reflect variable disequilibrium conditions (Ridolfi and Renzulli, 2012). 
Table 1. Continued.

\begin{tabular}{|c|c|c|c|c|c|c|c|c|c|c|}
\hline Samples & S- 48 & S-49 & S-50 & S-51 & S-52 & S-53 & S-54 & S-55 & S-56 & S-57 \\
\hline $\mathrm{SiO}_{2}$ & 67.54 & 70.12 & 65.53 & 65.78 & 67.15 & 69.97 & 66.83 & 64.91 & 67.89 & 66.39 \\
\hline $\mathrm{TiO}_{2}$ & 0.38 & 0.26 & 0.44 & 0.44 & 0.38 & 0.29 & 0.38 & 0.48 & 0.34 & 0.38 \\
\hline $\mathrm{Al}_{2} \mathrm{O}_{3}$ & 16.59 & 16.73 & 17.37 & 16.95 & 16.61 & 15.84 & 16.63 & 16.92 & 6.26 & 17.36 \\
\hline $\mathrm{FeO}$ & 1.30 & 0.89 & 1.47 & 1.47 & 1.29 & 0.95 & 1.32 & 1.71 & 1.15 & 1.29 \\
\hline $\mathrm{Fe}_{2} \mathrm{O}_{3}$ & 1.91 & 1.34 & 2.21 & 2.20 & 1.94 & 1.43 & 1.98 & 2.56 & 1.72 & 1.94 \\
\hline $\mathrm{MnO}$ & 0.06 & 0.03 & 0.05 & 0.05 & 0.06 & 0.04 & 0.05 & 0.04 & 0.06 & 0.03 \\
\hline $\mathrm{MgO}$ & 1.86 & 0.68 & 2.13 & 2.47 & 2.20 & 1.76 & 1.98 & 2.87 & 2.50 & 1.66 \\
\hline $\mathrm{CaO}$ & 4.20 & 3.48 & 4.83 & 4.80 & 4.37 & 4.08 & 4.16 & 4.79 & 4.26 & 5.08 \\
\hline $\mathrm{Na}_{2} \mathrm{O}$ & 4.13 & 3.45 & 4.76 & 4.73 & 4.29 & 3.98 & 4.09 & 4.72 & 4.16 & 4.96 \\
\hline $\mathrm{K}_{2} \mathrm{O}$ & 1.45 & 1.58 & 1.30 & 1.36 & 1.44 & 1.34 & 1.82 & 1.33 & 1.60 & 1.34 \\
\hline $\mathrm{P}_{2} \mathrm{O}_{5}$ & 0.15 & 0.14 & 0.21 & 0.20 & 0.15 & 0.07 & 0.13 & 0.19 & 0.14 & 0.20 \\
\hline L.O.I. & 1.51 & 0.75 & 1.41 & 1.45 & 1.79 & 2.33 & 1.64 & 1.48 & 2.21 & 2.4 \\
\hline Total & 99.96 & 99.94 & 99.95 & 99.96 & 99.97 & 99.96 & 99.95 & 99.97 & 99.97 & 99.97 \\
\hline $\mathrm{Ba}$ & 328 & 386 & 318 & 295 & 332 & 383 & 442 & 277 & 399 & 338 \\
\hline Cs & 0.60 & 0.39 & 0.80 & 0.79 & 0.60 & 0.90 & 1.18 & 0.60 & 0.90 & 0.79 \\
\hline $\mathrm{Ga}$ & 14.9 & 9.8 & 15.9 & 13.9 & 11.9 & 12.9 & 12.8 & 18.9 & 13.0 & 18.9 \\
\hline Hf & 2.0 & 2.0 & 2.0 & 2.0 & 2.0 & 2.0 & 2.0 & 2.0 & 2.0 & 2.0 \\
\hline $\mathrm{Nb}$ & 9 & 2.9 & 5.9 & 6.9 & 5 & 3 & 4 & 7.9 & 6 & 8 \\
\hline $\mathrm{Rb}$ & 20.2 & 18.9 & 18.9 & 17.3 & 17.3 & 24.2 & 22.6 & 18.6 & 26.9 & 24.3 \\
\hline $\mathrm{Sr}$ & 668.7 & 677.1 & 697 & 770.9 & 633.2 & 486.5 & 606.5 & 657.7 & 549 & 626.6 \\
\hline $\mathrm{Ta}$ & 0.595238 & 0.5 & 0.5 & 0.5 & 0.5 & 0.5 & 0.5 & 0.5 & 0.5 & 0.5 \\
\hline Th & 2.4 & 2.2 & 1.8 & 2.5 & 2.8 & 1.8 & 3 & 3 & 3 & 2.2 \\
\hline $\mathrm{U}$ & 0.84 & 0.76 & 0.62 & 0.83 & 0.81 & 0.80 & 0.99 & 0.83 & 0.96 & 0.82 \\
\hline $\mathrm{V}$ & 61.37 & 14.32 & 90.44 & 86.85 & 69.24 & 76.51 & 65.29 & 92.6 & 66.5 & 62.08 \\
\hline $\mathrm{Zr}$ & 80. & 61.8 & 83.5 & 66.5 & 61.6 & 66.7 & 55.9 & 93.5 & 81 & 109.2 \\
\hline $\mathrm{Y}$ & 5 & 6 & 7 & 7 & 6 & 6 & 6 & 8 & 6 & 10 \\
\hline $\mathrm{La}$ & 31.4 & 31.6 & 27.0 & 31.5 & 28.8 & 23.5 & 31.0 & 30.6 & 29.0 & 32.2 \\
\hline $\mathrm{Ce}$ & 23.8 & 26.5 & 20.9 & 26.8 & 22.9 & 14.9 & 25.5 & 24.9 & 22.0 & 26.8 \\
\hline $\operatorname{Pr}$ & 2.7 & 3.1 & 2.6 & 3.2 & 2.6 & 1.7 & 3.0 & 3.0 & 2.4 & 3.2 \\
\hline $\mathrm{Nd}$ & 9.5 & 11.8 & 9.9 & 11.9 & 9.7 & 6.7 & 10.8 & 10.9 & 8.8 & 11.9 \\
\hline $\mathrm{Sm}$ & 1.8 & 1.8 & 1.7 & 2.0 & 1.5 & 1.2 & 1.9 & 1.7 & 1.5 & 2.3 \\
\hline $\mathrm{Eu}$ & 0.6 & 0.6 & 0.7 & 0.7 & 0.6 & 0.5 & 0.6 & 0.7 & 0.5 & 0.7 \\
\hline $\mathrm{Gd}$ & 2.2 & 2.2 & 2.1 & 2.2 & 2.0 & 1.5 & 2.2 & 2.0 & 1.9 & 2.3 \\
\hline $\mathrm{Tb}$ & 0.2 & 0.2 & 0.2 & 0.2 & 0.2 & 0.2 & 0.2 & 0.2 & 0.2 & 0.2 \\
\hline Dy & 0.8 & 1.1 & 0.7 & 1.0 & 0.5 & 0.8 & 1.0 & 1.2 & 0.8 & 0.7 \\
\hline Ho & 0.2 & 0.2 & 0.2 & 0.2 & 0.2 & 0.2 & 0.2 & 0.2 & 0.2 & 0.2 \\
\hline $\mathrm{Er}$ & 0.6 & 0.7 & 0.5 & 0.6 & 0.5 & 0.5 & 0.7 & 0.6 & 0.6 & 0.6 \\
\hline $\mathrm{Yb}$ & 0.7 & 0.9 & 1.0 & 1.0 & 1.0 & 1.0 & 1.0 & 1.0 & 1.2 & 1.6 \\
\hline $\mathrm{Lu}$ & 0.1 & 0.1 & 0.1 & 0.1 & 0.1 & 0.1 & 0.1 & 0.1 & 0.1 & 0.1 \\
\hline $\mathrm{Sr} / \mathrm{Y}$ & 133.7 & 112.9 & 99.5 & 110.1 & 105.5 & 81.1 & 101.1 & 82.2 & 91.5 & 62.7 \\
\hline $\mathrm{La} / \mathrm{Yb}$ & 14.7 & 25.8 & 27.0 & 28.8 & 29.0 & 30.6 & 31.4 & 32.2 & 35.1 & 45.1 \\
\hline $\mathrm{Zr} / \mathrm{Sm}$ & 45.0 & 35.0 & 49.4 & 33.5 & 41.3 & 55.8 & 30.0 & 55.3 & 54.0 & 47.8 \\
\hline $\mathrm{Mg \#}$ & 58.9 & 43.0 & 59.1 & 62.7 & 63.0 & 65.0 & 60.0 & 62.7 & 68.5 & 56.2 \\
\hline $\mathrm{Eu} / \mathrm{Eu}^{*}$ & 1.0 & 1.0 & 1.1 & 1.1 & 1.0 & 1.1 & 0.9 & 1.2 & 0.9 & 0.9 \\
\hline $\mathrm{A} / \mathrm{CNK}$ & 0.9 & 1 & 1.2 & 1.1 & 1 & 0.9 & 0.9 & 0.9 & 1 & 1 \\
\hline
\end{tabular}

\subsection{Plagioclase-melt thermobarometry}

To test and complement the results of the amphibole thermobarometry, the plagioclase-melt thermobarometer of Putirka (2008), calibrated for hydrous systems, was put to use. The standard error of estimation (SEE) for this thermobarometer is $\pm 36^{\circ} \mathrm{C}$ and $\pm 247 \mathrm{MPa}$ (Putirka 2008), which is less precise than the amphibole barometer employed. The most commonly used nominal melts are whole rock, groundmass and glass compositions (Putirka et al., 2003; Putirka, 2008), and the respective whole rocks were applied as the nominal melt in our study. 


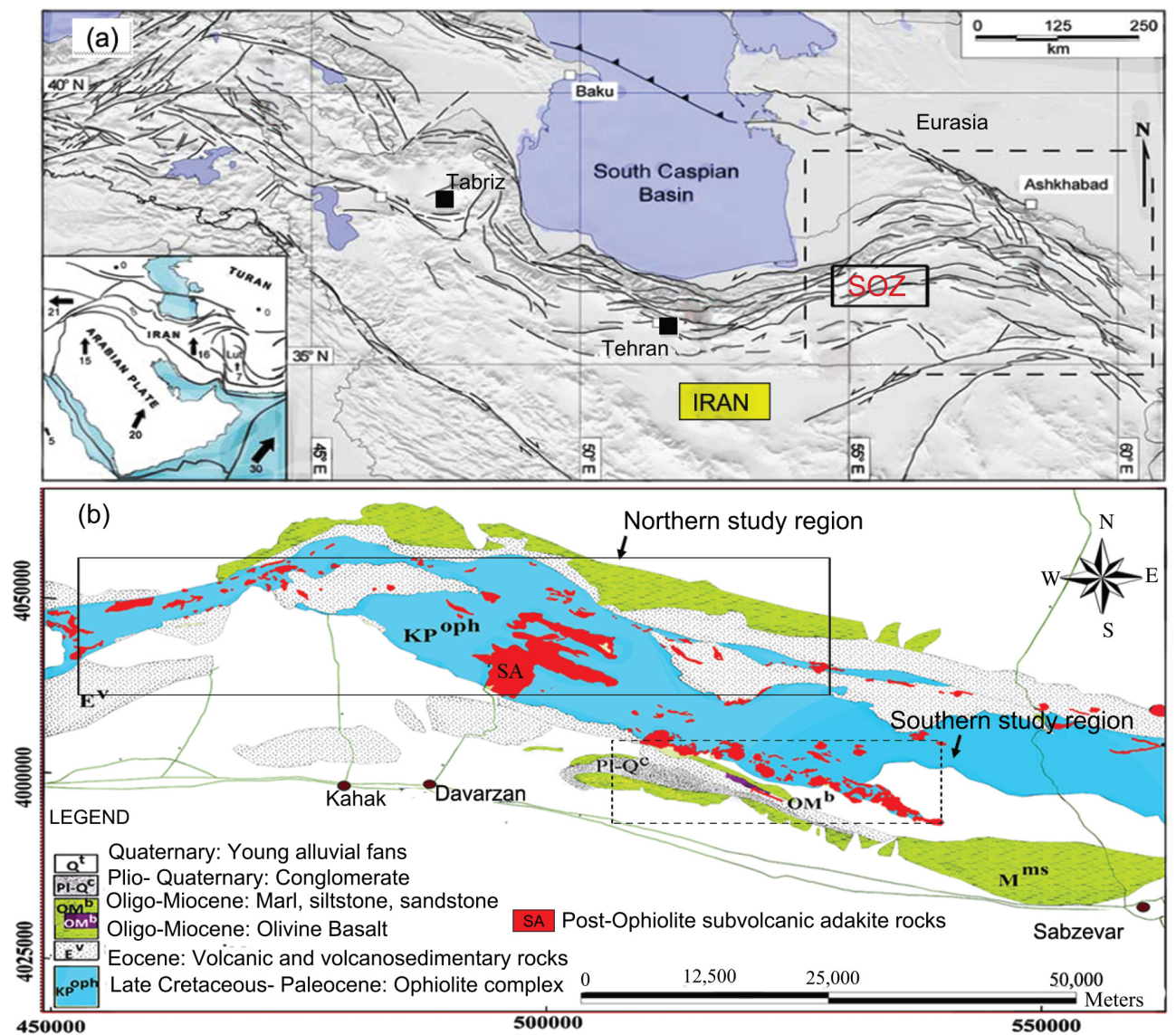

Figure 1. (a) Shaded relief image (after Shabanian et al., 2012) showing the location of the Sabzevar ophiolitic zone (SOZ). The lower left inset shows the geodynamic setting of Arabia-Eurasia collision/subduction framework. Black arrows and associated numbers represent the present-day Arabia-Eurasia plate movement velocities according to Reilinger et al. (2006) in $\mathrm{mm} \mathrm{yr}^{-1}$. (b) Simplified geological map of the Sabzevar area and the post-ophiolite subvolcanic rocks. The northern (solid rectangle) and southern (dashed rectangle) sector of the study area are indicated.

\subsection{Clinopyroxene-melt barometry}

This barometry model for clinopyroxene-melt equilibria after Putirka (2008, Eq. A3) has been applied to cross-check the result from amphibole and plagioclase-melt barometry. This model is based on $\mathrm{Al}$ partitioning between clinopyroxene and coexisting melt in hydrous magmatic systems. The SEE for this barometer is $\pm 150 \mathrm{MPa}$, and the respective input melt was the corresponding whole rock composition (cf. Putirka, 2008).

\subsection{Equilibrium tests}

Putirka (2008) present an equilibrium test for plagioclasemelt thermobarometry based on the partitioning coefficients of the anorthite and albite components, $\mathrm{Kd}[\mathrm{An}-\mathrm{Ab}]$. The equilibrium constant is sensitive to temperature and should be $0.10 \pm 0.05$ at $T<1050^{\circ} \mathrm{C}$ and $0.27 \pm 0.11$ at $T>1050^{\circ} \mathrm{C}$ (Putirka, 2008). The plagioclase components that are near to equilibrium with a given melt at the given pressure and temperature conditions should fall within the $\mathrm{Kd}_{[\mathrm{An}-\mathrm{Ab}]}$ envelope appropriate for this melt and mineral composition.

Clinopyroxene-melt equilibrium was tested using two models. Firstly, we looked at the partition coefficient of $\mathrm{Fe}$ and $\mathrm{Mg}$ between clinopyroxene and melt. According to Putirka (2008), the acceptable range of equilibrium values for $\mathrm{Kd}_{[\mathrm{Fe}-\mathrm{Mg}]}$ is $0.28 \pm 0.08$. We tested our available whole rocks as nominal melts. A melt that plots within the $\mathrm{Kd}_{[\mathrm{Fe}-\mathrm{Mg}]}=0.28 \pm 0.08$ boundary can thus be assumed to represent a liquid in potential equilibrium with the analyzed clinopyroxenes. All data points plotted within this range were further tested using the equilibrium test presented in Putirka (1999), based on the equilibrium partitioning of $\mathrm{Na}$ $\mathrm{Ca}-\mathrm{Al}$. Here, predicted values of different components that crystallize from a nominal melt are compared with observed clinopyroxene components, and mineral-melt equilibrium pairs require a close match between predicted and observed components to satisfy equilibrium conditions. 
Table 2. Representative compositions of amphiboles from post-ophiolite rocks in the Sabzevar zone.

\begin{tabular}{|c|c|c|c|c|c|c|c|c|c|c|c|c|c|c|}
\hline \multirow{3}{*}{$\begin{array}{l}\text { Mineral } \\
\begin{array}{l}\text { Host rock } \\
\text { position }\end{array}\end{array}$} & \multicolumn{2}{|c|}{$\begin{array}{l}\text { Unzoned- } \\
\text { amphibole }\end{array}$} & \multicolumn{2}{|c|}{$\begin{array}{l}\text { Simple-zoned } \\
\text { amphibole }\end{array}$} & \multicolumn{2}{|c|}{$\begin{array}{l}\text { Simple-zoned } \\
\text { amphibole }\end{array}$} & \multicolumn{2}{|c|}{$\begin{array}{l}\text { Simple-zoned } \\
\text { amphibole }\end{array}$} & \multicolumn{3}{|c|}{$\begin{array}{l}\text { Oscillatory-zoned } \\
\text { amphibole }\end{array}$} & \multicolumn{3}{|c|}{$\begin{array}{l}\text { Amphibole in } \\
\text { crystal clots }\end{array}$} \\
\hline & \multirow{2}{*}{\multicolumn{2}{|c|}{$\begin{array}{l}\mathrm{N}-1 \text { (andesite) } \\
\text { core rim }\end{array}$}} & \multicolumn{2}{|c|}{ N-11 (trachyandesite) } & \multicolumn{2}{|c|}{ N-12 (trachydacite) } & \multicolumn{2}{|c|}{ N-12(trachydacite) } & \multicolumn{3}{|c|}{ N-4 (trachydacite) } & \multicolumn{3}{|c|}{ N-6 (trachyandesite) } \\
\hline & & & core & rim & core & rim & core & rim & core & bright zone & rim & rim & core & rim \\
\hline $\mathrm{SiO}_{2}$ & 41.03 & 40.71 & 44.19 & 46.18 & 42.6 & 45.31 & 45.66 & 47.68 & 46.09 & 47.73 & 44.98 & 43.19 & 44.63 & 43.79 \\
\hline $\mathrm{TiO}_{2}$ & 3.55 & 3.12 & 1.56 & 1.42 & 1.24 & 1.62 & 1.33 & 2.40 & 1.66 & 1.03 & 1.45 & 1.91 & 2.19 & 2.28 \\
\hline $\mathrm{Al}_{2} \mathrm{O}_{3}$ & 12.77 & 12.58 & 11.81 & 11.1 & 13.43 & 11.16 & 12.04 & 8.65 & 11.52 & 8.79 & 11.11 & 11.89 & 10.96 & 11.86 \\
\hline $\mathrm{FeO}$ & 10.11 & 9.89 & 13.44 & 11.06 & 15 & 11.87 & 9.26 & 11.55 & 9.15 & 12.25 & 13.06 & 12.99 & 12.61 & 12.69 \\
\hline $\mathrm{MnO}$ & 0.06 & 0 & 0.26 & 0.14 & 0.24 & 0 & 0.09 & 0.23 & 0.23 & 0.32 & 0.25 & 0.06 & 0.11 & 0.00 \\
\hline $\mathrm{MgO}$ & 14.53 & 14.95 & 13.37 & 16.02 & 11.36 & 15.17 & 16.54 & 15.06 & 16.65 & 14.77 & 14.02 & 14.15 & 14.31 & 13.79 \\
\hline $\mathrm{CaO}$ & 11.99 & 12.05 & 11.69 & 10.75 & 10.58 & 10.71 & 11.07 & 10.28 & 11.04 & 11.19 & 11.55 & 11.16 & 11.12 & 11.06 \\
\hline $\mathrm{Na}_{2} \mathrm{O}$ & 2.45 & 2.61 & 2.11 & 2.31 & 2.41 & 2.33 & 2.28 & 2.22 & 2.31 & 1.68 & 2.3 & 2.09 & 2.09 & 2.22 \\
\hline $\mathrm{K}_{2} \mathrm{O}$ & 0.96 & 0.99 & 0.16 & 0.16 & 0.30 & 0.12 & 0.36 & 0.34 & 0.2 & 0.19 & 0.18 & 0.28 & 0.29 & 0.37 \\
\hline $\mathrm{Cr}_{2} \mathrm{O}_{3}$ & 0.03 & 0.12 & 0.07 & 0.06 & 0.01 & 0.01 & 0.00 & 0.05 & 0.07 & 0.04 & 0.02 & 0.00 & 0.01 & 0.01 \\
\hline Total & 97.47 & 97.02 & 98.67 & 99.21 & 97.18 & 98.30 & 98.63 & 98.57 & 98.95 & 98.00 & 98.93 & 97.73 & 98.33 & 98.07 \\
\hline \multicolumn{15}{|c|}{ Amphibole formula on the basis of 13 cations Leake et al. (1997) } \\
\hline $\mathrm{Si}$ & 6.00 & 5.98 & 6.41 & 6.41 & 6.22 & 6.39 & 6.36 & 6.74 & 6.40 & 6.79 & 6.41 & 6.19 & 6.36 & 6.28 \\
\hline $\mathrm{Al}^{i v}$ & 2.00 & 2.02 & 1.59 & 1.59 & 1.78 & 1.61 & 1.64 & 1.26 & 1.60 & 1.21 & 1.59 & 1.81 & 1.64 & 1.72 \\
\hline $\mathrm{Al}^{v i}$ & 0.20 & 0.15 & 0.23 & 0.23 & 0.53 & 0.24 & 0.34 & 0.18 & 0.28 & 0.26 & 0.28 & 0.20 & 0.21 & 0.28 \\
\hline $\mathrm{Ti}$ & 0.39 & 0.34 & 0.15 & 0.15 & 0.14 & 0.17 & 0.14 & 0.25 & 0.17 & 0.11 & 0.16 & 0.21 & 0.23 & 0.25 \\
\hline $\mathrm{Fe}^{+3}$ & 0.39 & 0.44 & 1.21 & 1.21 & 0.93 & 1.14 & 1.04 & 0.79 & 1.02 & 0.82 & 0.80 & 1.13 & 0.93 & 0.86 \\
\hline $\mathrm{Mg}$ & 3.17 & 3.27 & 3.32 & 3.32 & 2.47 & 3.19 & 3.43 & 3.17 & 3.45 & 3.13 & 2.98 & 0.43 & 0.57 & 0.66 \\
\hline $\mathrm{Fe}^{+2}$ & 0.84 & 0.77 & 0.08 & 0.08 & 0.90 & 0.26 & 0.04 & 0.57 & 0.04 & 0.63 & 0.75 & 0.01 & 0.01 & 0.00 \\
\hline $\mathrm{Mn}$ & 0.01 & 0.00 & 0.02 & 0.02 & 0.03 & 0.00 & 0.01 & 0.03 & 0.03 & 0.04 & 0.03 & 3.03 & 3.04 & 2.95 \\
\hline $\mathrm{Ca}$ & 1.88 & 1.90 & 1.79 & 1.60 & 1.65 & 1.62 & 1.65 & 1.56 & 1.64 & 1.70 & 1.76 & 1.71 & 1.70 & 1.70 \\
\hline $\mathrm{Na}$ & 0.57 & 0.64 & 0.38 & 0.22 & 0.34 & 0.25 & 0.27 & 0.16 & 0.26 & 0.17 & 0.40 & 0.58 & 0.58 & 0.62 \\
\hline $\mathrm{K}$ & 0.18 & 0.19 & 0.03 & 0.03 & 0.06 & 0.02 & 0.06 & 0.06 & 0.04 & 0.03 & 0.03 & 0.05 & 0.05 & 0.07 \\
\hline
\end{tabular}

Table 3. Representative compositions of plagioclases from post-ophiolite rocks in Sabzevar zone.

\begin{tabular}{|c|c|c|c|c|c|c|c|c|c|c|c|}
\hline \multirow{3}{*}{$\begin{array}{l}\text { Mineral } \\
\begin{array}{l}\text { Host rock } \\
\text { position }\end{array}\end{array}$} & \multicolumn{2}{|c|}{ Plagioclase } & \multicolumn{2}{|c|}{$\begin{array}{l}\text { Normal-zoned } \\
\text { plagioclase }\end{array}$} & \multicolumn{3}{|c|}{ Oscillatory-zoned plagioclase } & \multicolumn{2}{|c|}{$\begin{array}{l}\text { Sieved texture } \\
\text { plagioclase }\end{array}$} & \multicolumn{2}{|c|}{ Plagioclase } \\
\hline & \multicolumn{2}{|c|}{ N-10 (andesite) } & \multicolumn{2}{|c|}{$\begin{array}{l}\mathrm{N}-11 \text { (trachyandesite) } \\
\text { core rim }\end{array}$} & \multicolumn{3}{|c|}{$\mathrm{N}-17$ (dacite) } & \multicolumn{2}{|c|}{$\mathrm{N}-18$ (dacite) } & \multicolumn{2}{|c|}{ S-37 (rhyolite) } \\
\hline & core & rim & core & rim & core & inner zone & rim & core & rim & core & rim \\
\hline $\mathrm{SiO}_{2}$ & 51.37 & 53.32 & 58.99 & 61.88 & 63.58 & 54.97 & 60.38 & 67.11 & 58.68 & 67.66 & 68.50 \\
\hline $\mathrm{TiO}_{2}$ & 0.08 & 0.04 & 0.07 & 0.01 & 0 & 0.054 & 0 & 0.02 & 0.02 & 0 & 0.00 \\
\hline $\mathrm{Al}_{2} \mathrm{O}_{3}$ & 30.63 & 29.62 & 26.90 & 24.80 & 23.72 & 28.27 & 25.64 & 22.22 & 27.07 & 21.58 & 20.54 \\
\hline $\mathrm{FeO}$ & 0.58 & 0.55 & 0.18 & 0.14 & 0.08 & 0.22 & 0.17 & 0.12 & 0.41 & 0 & 0.05 \\
\hline $\mathrm{MnO}$ & 0.00 & 0.00 & 0.00 & 0.03 & 0 & 0.03 & 0.03 & 0 & 0 & 0.1157 & 0.18 \\
\hline $\mathrm{MgO}$ & 0.08 & 0.06 & 0.01 & 0.00 & 0.02 & 0 & 0 & 0.04 & 0.02 & 0.0089 & 0.00 \\
\hline $\mathrm{CaO}$ & 14.04 & 13.00 & 9.15 & 7.03 & 5.61 & 11.32 & 8.09 & 4.09 & 9.54 & 2.63 & 2.32 \\
\hline $\mathrm{Na}_{2} \mathrm{O}$ & 3.25 & 3.88 & 4.57 & 5.99 & 7.34 & 5.1 & 5.64 & 6.59 & 5.69 & 7.95 & 7.45 \\
\hline $\mathrm{K}_{2} \mathrm{O}$ & 0.08 & 0.15 & 0.08 & 0.12 & 0.36 & 0.14 & 0.26 & 0.46 & 0.23 & 0.4767 & 0.55 \\
\hline $\mathrm{Cr}_{2} \mathrm{O}_{3}$ & 0.03 & 0.00 & 0.00 & 0.01 & 0 & 0 & 0 & 0 & 0 & 0.0074 & 0.00 \\
\hline Total & 100.14 & 100.61 & 99.96 & 100.01 & 100.72 & 100.11 & 100.22 & 100.67 & 101.66 & 100.4287 & 99.59 \\
\hline \multicolumn{12}{|c|}{ Feldspar components } \\
\hline An & 0.70 & 0.65 & 0.52 & 0.39 & 0.29 & 0.55 & 0.43 & 0.25 & 0.47 & 0.15 & 0.14 \\
\hline $\mathrm{Ab}$ & 0.29 & 0.34 & 0.47 & 0.60 & 0.69 & 0.45 & 0.55 & 0.72 & 0.51 & 0.82 & 0.82 \\
\hline Or & 0.00 & 0.01 & 0.01 & 0.01 & 0.02 & 0.01 & 0.02 & 0.03 & 0.01 & 0.03 & 0.04 \\
\hline
\end{tabular}

\section{Results}

\subsection{Petrography}

Post-ophiolite magmatism in the northern part of the

Sabzevar belt comprises intermediate rocks of andesite, 

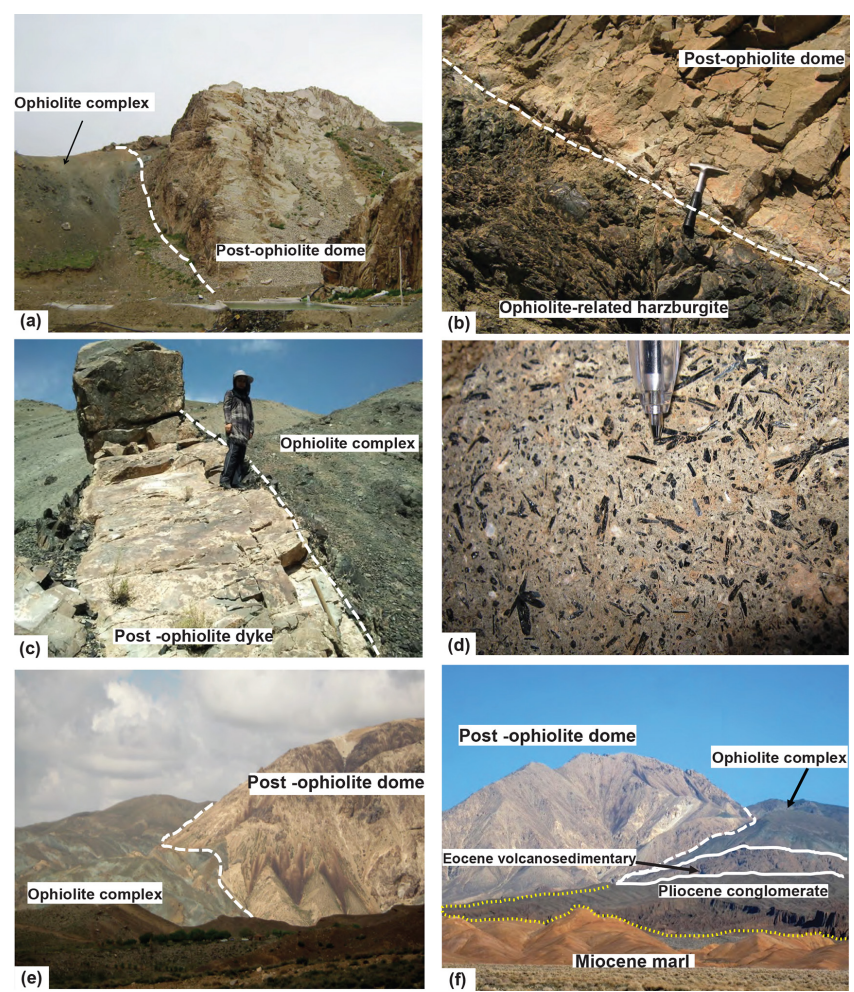

Figure 2. Field photographs. (a) and (b) Northern grey dome of trachydacite exposed in ophiolite-related harzburgite. (b) Contact between post-ophiolite subvolcanic rock and host harzburgite. (c) Post-ophiolite dyke in the northern sector. (d) Presence of star-shape amphibole aggregates in the andesitic dyke. (e) and (f) Southern post-ophiolite domes that outcrop in the ophiolite complex. Eocene volcaniclastic complex, Miocene sedimentary and Pliocene conglomerates are seen in (f).

trachyandesite and trachydacite to dacite composition. Andesite/trachyandesite rocks intrude into the ophiolite complex and younger volcanoclastic rocks and appear as greygreen dome-forming intrusions in the field, but also occur as dykes. In thin sections, the andesite/trachyandesite rocks show porphyritic, acicular and fluidal textures and contain plagioclase and amphibole as the main minerals, together with variable amounts of plagioclase, biotite and $\mathrm{Fe}-\mathrm{Ti}$ oxide microlites in the groundmass (Fig. 4a, b). Clinopyroxene phenocrysts of mostly diopside to augite composition are only found in high Mg-andesite samples (Fig. 4c). Notably, this rock is a mafic basaltic andesite and shows amphibole and clinopyroxene phenocrysts but lacks plagioclase as a phenocryst phase. Amphibole phenocrysts are generally star shaped or long prisms up to $1 \mathrm{~cm}$, and the groundmass of the dyke is composed of fine-grained hornblende, plagioclase and augite.

Euhedral to subhedral biotite is present and in more evolved trachydacites and is moderately enriched in $\mathrm{Mg}$ (average $\mathrm{Mg \#} \approx 0.65$ ). Monomineralic glomerocrysts of amphibole do occur occasionally in the trachyandesite samples.
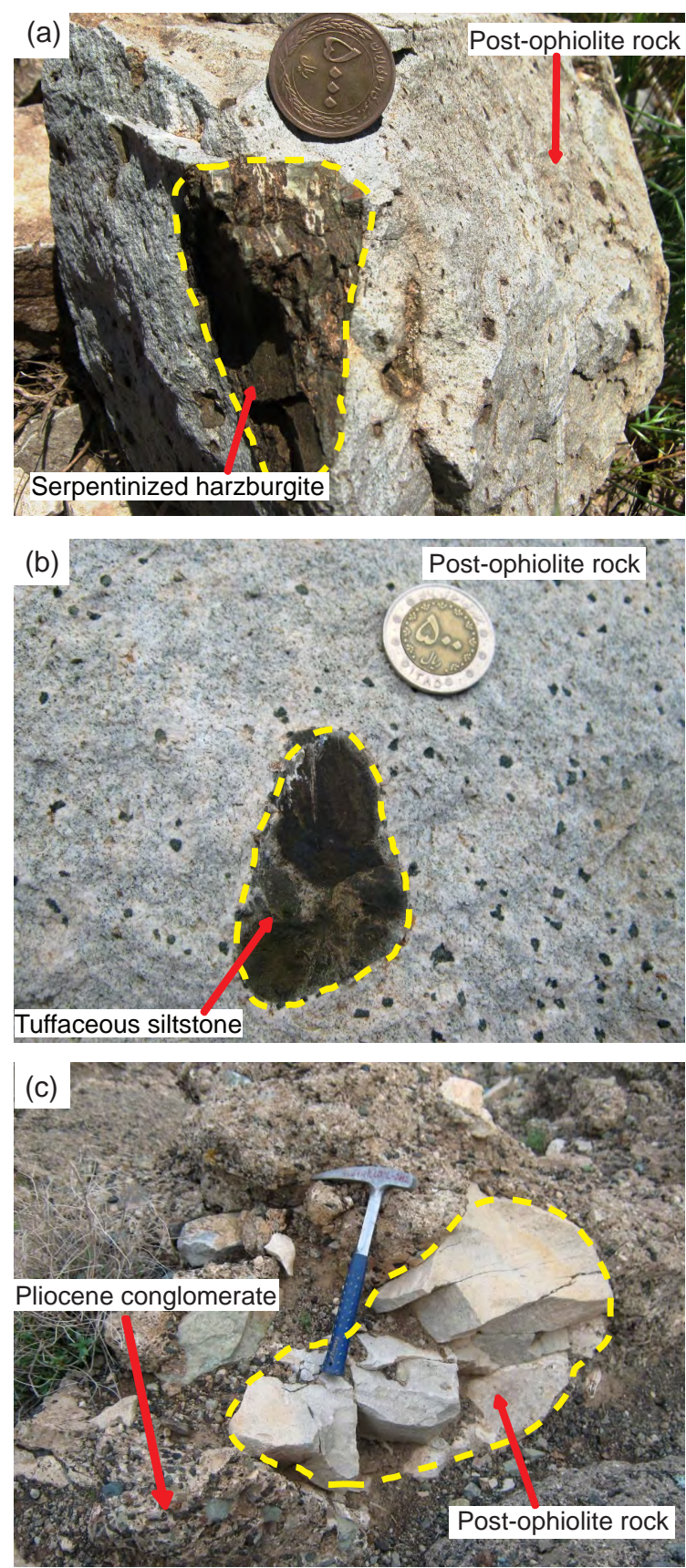

Figure 3. (a, b) Field photographs of host rock xenoliths. (a) Harzburgite belonging to a ophiolite complex. (b) Eocene tuffaceous siltstone. (c) Rhyolitic fragments in the Pliocene conglomerate.

Accessory minerals include apatite, Fe-Ti oxides and rare alkali feldspar. Apatite is ubiquitous, occurring as euhedral needle-like phenocrystals and as inclusions in larger phenocrysts. Fe-Ti oxides (mostly magnetite) occur as euhedral microphenocrysts and as inclusions in amphibole and biotite. Some trachyandesite samples also contain small but coarsegrained and rounded crystal clots up to $2 \mathrm{~mm}$ in diameter 

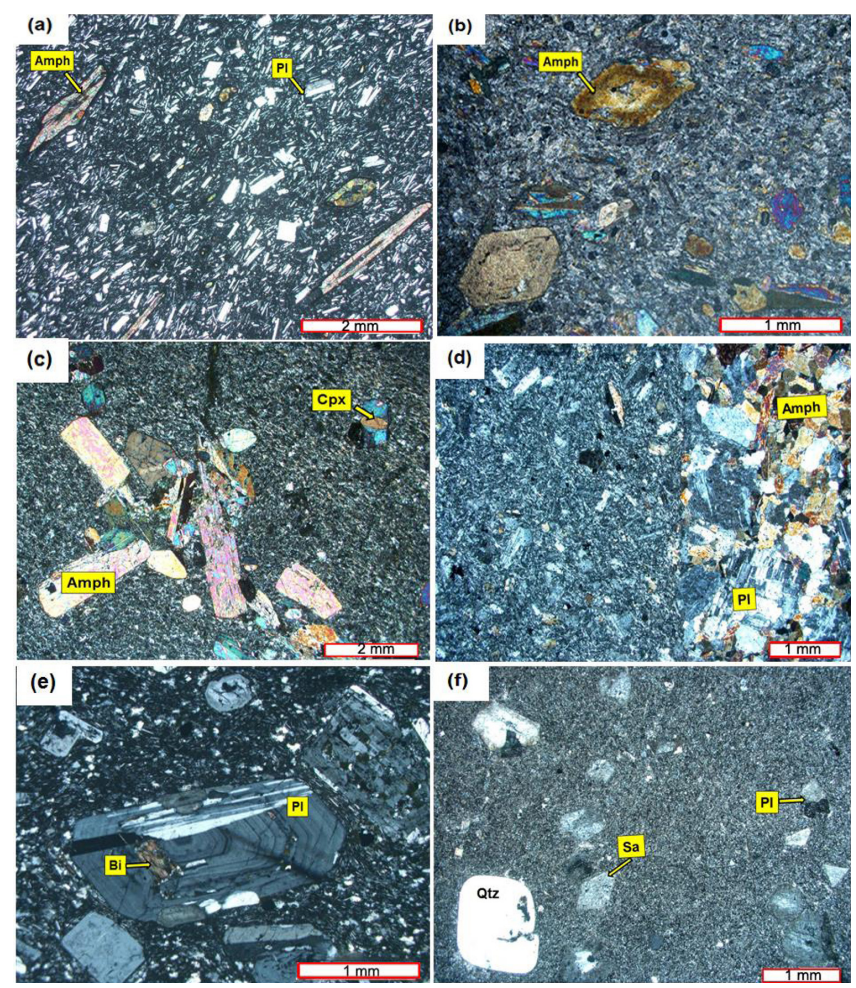

Figure 4. Representative photomicrographs (XPL). (a) Flow texture and presence of acicular amphiboles and plagioclases in andesite. (b) Euhedral to subhedral amphiboles with compositional zoning in trachyandesite. (c) Photomicrograph of amphibole and clinopyroxene phenocrysts in a fine-grain matrix in andesite. (d) Photomicrograph showing contact between crystal clot containing plagioclase and amphibole and host trachyandesite rock. (e) Zoned plagioclase phenocryst in decite. (f) Embayment and rounded quartz, altered sanidine and plagioclase in rhyolite.

(Fig. 4d) that are made up of euhedral microcrystals of plagioclase, amphibole and accessory apatite.

Dacite samples from light-grey domes and dykes show plagioclase as the volumetrically dominant phenocryst phase, which usually displays polysynthetic twinning and compositional zoning (Fig. 4e). Amphibole and biotite phenocrysts are apparent, and the medium to fine-grained groundmass is usually composed of plagioclase and amphibole microcrystals, with biotite, Fe-Ti oxides and apatite occurring in smaller proportions.

Felsic rock types of broadly dacite to rhyolite in composition crop out as dominantly light grey to white-colored domes in the southern and southwestern part of the Sabzevar belt. Like the dacite samples from the northern part, dacite domes in the southwestern part represent plagioclase phenocrysts, biotite and, rarely, amphibole in their fine-grained groundmass. Southern rhyolite samples show Quartz, sanidine and plagioclase phenocrysts with a fine-grained groundmass (Fig. 4f). Although smaller quartz phenocrysts have frequently straight edges, many large crystals display em-
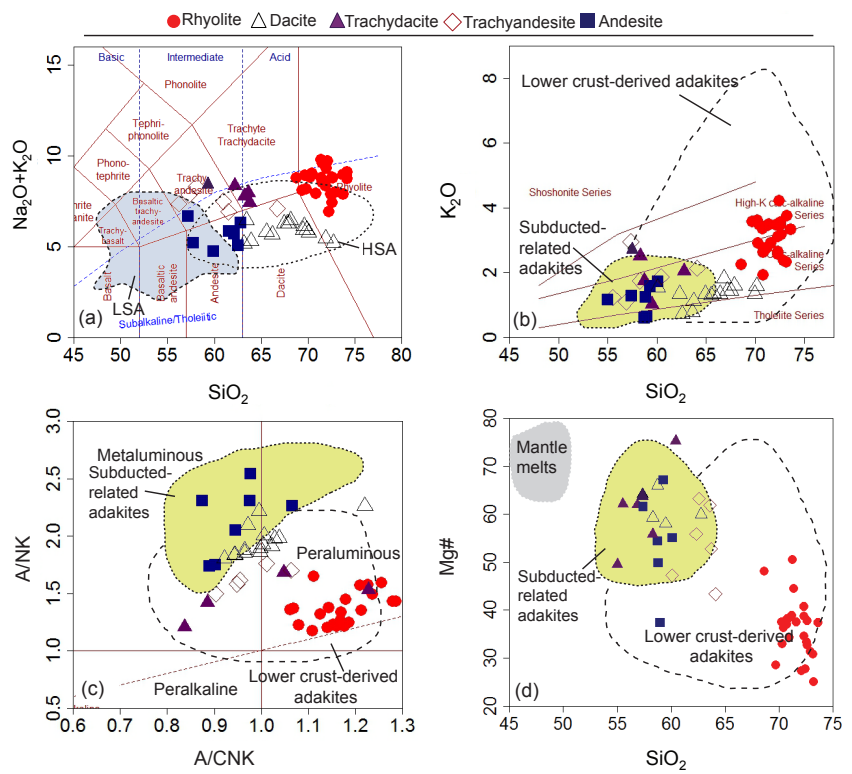

Figure 5. Selected major element plots for the subvolcanic postophiolite rocks. (a) Total alkalis vs. silica diagram after Le Bas et al. (1986). The boundary between alkaline and subalkaline series is after Irvine and Baragar (1971), and the fields of low-silica adakites (LSA) and high-silica adakites (HSA) are after Martin et al. (2005). (b) $\mathrm{K}_{2} \mathrm{O}$ vs. $\mathrm{SiO}_{2}$ diagram (after Peccerillo and Taylor, 1976); (c) A/CNK vs. A/NK diagram (Maniar and Piccoli, 1989); (d) Mg\# vs. $\mathrm{SiO}_{2}$ diagram. The fields of subduction-related adakites and lower crust-derived adakites are from Guan et al. (2012).

bayments and round edges. Some embayments are short and close to the margin, whereas others penetrate deep into the core of the grains. The most suitable process to explain deep embayments in quartz is dissolution in superheated and $\mathrm{H}_{2} \mathrm{O}-$ saturated rhyolite melt due to ascent and decompression or magma mixing (e.g., Donaldson and Henderson, 1989; Chang and Meinert, 2004). White-colored sanidine also occurs and has a subhedral form, but is often altered. Intensely altered grains of sanidine are cloudy and turbid and were not selected for microprobe analysis.

\subsection{Whole rock geochemistry}

For the purpose of plotting, all oxide values have been normalized to $100 \%$ (volatile free), and iron content is given as $\mathrm{FeO}_{\text {total }}$. The samples from the northern part have $\mathrm{SiO}_{2}$ contents of 55 to $64.0 \mathrm{wt} \%$ and fall into the andesite, trachyandesite, trachydacite and dacite fields of the total alkali vs. silica diagram (TAS; Fig. 5a). They have low $\mathrm{TiO}_{2}(0.4-0.7 \mathrm{wt} \%)$ and high $\mathrm{Al}_{2} \mathrm{O}_{3}$ contents $(14.2-19.1 \mathrm{wt} \%) . \quad \mathrm{K}_{2} \mathrm{O}$ contents $(0.6-2.9 \mathrm{wt} \%)$ are less than $\mathrm{Na}_{2} \mathrm{O}$ (3.9-7 wt \%), belonging to the calc-alkaline (Fig. 5b) and metaluminous to peraluminous (Fig. 5c) series. $\mathrm{Mg} \#(100 \times \mathrm{MgO} /[\mathrm{MgO}+\mathrm{FeO}])$ ranges from 37.5 to 75 (Fig. 5d). Strong negative correlations can be observed in 
Table 4. Representative compositions of clinopyroxenes from post-ophiolite rocks in Sabzevar zone.

\begin{tabular}{|c|c|c|c|c|c|c|c|c|c|}
\hline \multirow{3}{*}{$\begin{array}{l}\text { Mineral } \\
\text { Host rock } \\
\text { Position }\end{array}$} & \multicolumn{9}{|c|}{ Cpx } \\
\hline & \multicolumn{2}{|c|}{ N-1 (andesite) } & \multicolumn{2}{|c|}{ N-1 (andesite) } & \multicolumn{2}{|c|}{ N-1 (andesite) } & \multicolumn{3}{|c|}{ N-1 (andesite) } \\
\hline & core & rim & core & rim & rim & core & $\operatorname{rim}$ & core & rim \\
\hline $\mathrm{SiO}_{2}$ & 48.82 & 49.01 & 53.27 & 49.02 & 49.72 & 48.94 & 52.7 & 53.58 & 53.54 \\
\hline $\mathrm{TiO}_{2}$ & 1.33 & 1.28 & 0.53 & 0.84 & 1.19 & 1.44 & 0.32 & 0.33 & 0.36 \\
\hline $\mathrm{Al}_{2} \mathrm{O}_{3}$ & 5.16 & 4.40 & 2.29 & 2.81 & 4.41 & 4.91 & 2 & 1.98 & 2.31 \\
\hline $\mathrm{FeO}$ & 7.08 & 7.77 & 5.46 & 6.66 & 7.04 & 7.41 & 6.06 & 5.92 & 6 \\
\hline $\mathrm{MnO}$ & 0.06 & 0.22 & 0.09 & 0.22 & 0.15 & 0 & 0.21 & 0.21 & 0.3 \\
\hline $\mathrm{MgO}$ & 13.68 & 14.49 & 16.49 & 15.49 & 14.64 & 13.67 & 16.52 & 16.69 & 16.45 \\
\hline $\mathrm{CaO}$ & 22.89 & 21.79 & 22.26 & 22.07 & 21.91 & 22.91 & 21.5 & 21.38 & 21.16 \\
\hline $\mathrm{Na}_{2} \mathrm{O}$ & 0.34 & 0.39 & 0.40 & 0.42 & 0.49 & 0.42 & 0.43 & 0.37 & 0.40 \\
\hline $\mathrm{K}_{2} \mathrm{O}$ & 0.00 & 0.02 & 0.30 & 0.00 & 0.02 & 0.00 & 0.01 & 0.00 & 0.02 \\
\hline $\mathrm{Cr}_{2} \mathrm{O}_{3}$ & 0.01 & 0.00 & 0.30 & 0.02 & 0.05 & 0.00 & 0.25 & 0.29 & 0.26 \\
\hline Total & 99.37 & 99.35 & 101.12 & 97.55 & 99.96 & 99.71 & 100.00 & 100.76 & 100.79 \\
\hline $\mathrm{Si}$ & 1.77 & 1.94 & 1.94 & 1.78 & 1.81 & 1.78 & 1.91 & 1.95 & 1.95 \\
\hline $\mathrm{Ti}$ & 0.04 & 0.01 & 0.01 & 0.02 & 0.03 & 0.04 & 0.01 & 0.01 & 0.01 \\
\hline $\mathrm{Al}$ & 0.17 & 0.07 & 0.07 & 0.09 & 0.14 & 0.16 & 0.06 & 0.08 & 0.07 \\
\hline $\mathrm{Al}^{\mathrm{IV}}$ & 0.23 & 0.06 & 0.06 & 0.22 & 0.19 & 0.22 & 0.08 & 0.05 & 0.05 \\
\hline $\mathrm{Al}^{\mathrm{VI}}$ & 0.01 & 0.01 & 0.01 & 0.02 & 0.05 & 0.06 & 0.02 & 0.03 & 0.02 \\
\hline $\mathrm{Fe}^{2+}$ & 0.22 & 0.17 & 0.17 & 0.21 & 0.22 & 0.23 & 0.18 & 0.18 & 0.18 \\
\hline $\mathrm{Mn}$ & 0.00 & 0.00 & 0.00 & 0.01 & 0.00 & 0.00 & 0.01 & 0.01 & 0.01 \\
\hline $\mathrm{Mg}$ & 0.76 & 0.89 & 0.89 & 0.88 & 0.81 & 0.76 & 0.90 & 0.90 & 0.89 \\
\hline $\mathrm{Ca}$ & 0.92 & 0.87 & 0.87 & 0.90 & 0.88 & 0.92 & 0.85 & 0.83 & 0.82 \\
\hline $\mathrm{Na}$ & 0.02 & 0.03 & 0.03 & 0.03 & 0.04 & 0.03 & 0.03 & 0.02 & 0.03 \\
\hline Mg\# & 0.77 & 0.84 & 0.84 & 0.81 & 0.79 & 0.78 & 0.83 & 0.83 & 0.83 \\
\hline
\end{tabular}

Harker diagrams for $\mathrm{TiO}_{2}, \mathrm{FeO}_{\text {total }}, \mathrm{MgO}, \mathrm{CaO}$ and $\mathrm{Zr} / \mathrm{Nb}$ ratio vs. $\mathrm{SiO}_{2}$, but positive trends for $\mathrm{Na}_{2} \mathrm{O}, \mathrm{K}_{2} \mathrm{O}, \mathrm{La} / \mathrm{Yb}$, $\mathrm{Rb} / \mathrm{Sr}$ and $\mathrm{Sr} / \mathrm{Y}$ ratios are likewise observed (Fig. 6), indicating magmatic crystallization and associated differentiation due to enrichment in incompatible elements. Also, the decrease of $\mathrm{Dy} / \mathrm{Yb}$ (Fig. 61) combined with an increase in $\mathrm{Sr} / \mathrm{Y}$ (Fig. 6h) ratios with differentiation is consistent with partition coefficient of these elements between amphibole and tonalite melts, i.e., $D_{\mathrm{Dy}} / D_{\mathrm{Yb}}<1$ and $D_{\mathrm{Sr}} / D_{\mathrm{Y}}<1$ (Klein et al., 1997; Bédard, 2006; Davidson et al., 2007; Tiepolo et al., 2007; Rossetti et al., 2014). Multi-element mantle-normalized and REE chondrite-normalized plots for these samples (Fig. 7a, b) show typical subduction-related trace element patterns, including enrichments in LILE elements relative to LREEs (e.g., Ba/La), but with both groups being enriched relative to their HFSEs (e.g., $\mathrm{Ba} / \mathrm{Nb}$; $\mathrm{La} / \mathrm{Nb}$ ). According to these plots, the rocks are also characterized by an overall enrichment in LREEs relative to HREEs of, on average, $(\mathrm{La} / \mathrm{Yb})_{N}=7.9, \mathrm{U}$ and $\mathrm{Zr}$ depletions in HFSEs and absent Eu anomaly, which are typical features of adakite-type rock compositions (e.g., Defant and Drummond, 1990). The samples also contain high concentrations of $\mathrm{Sr}$ (avg. $460 \mathrm{ppm})$ and low concentrations of Y (5-19 ppm) and $\mathrm{Yb}(0.4-2 \mathrm{ppm})$ compared to typical arc volcanics; in the Y vs. Sr / Y diagram (Fig. 8a) most of the samples plot in the field of adakite rocks as opposed to typical arc-related calc-alkaline composition (cf. Defant and Drummond; 1990). However, a few samples plot near the intersection of the adakite and the arc-related fields, while a plot of $\mathrm{Sr}$ against $\mathrm{CaO}+\mathrm{Na}_{2} \mathrm{O}$ (after Castillo; 2011) shows most of our samples in the high-silica adakite field (Fig. 8b).

Notably, the samples of the southern part have higher silica contents than the northern suite and range from 65 to $73.6 \mathrm{wt} \%$ in $\mathrm{SiO}_{2}$, falling into the dacite and rhyolite field of the TAS diagram (Fig. 5a). They have high alkali contents with $\mathrm{K}_{2} \mathrm{O}$ contents of 1.3 to $4.2 \mathrm{wt} \%$ and $\mathrm{Na}_{2} \mathrm{O}$ of 3.5 to $7.1 \mathrm{wt} \%$, resulting in $\mathrm{Na}_{2} \mathrm{O} / \mathrm{K}_{2} \mathrm{O}$ ratios of 2.2 to 3.7 ; the rocks classify as calc-alkaline to high- $\mathrm{K}$ calc-alkaline and peraluminous (Fig. $5 \mathrm{~b}$ and c). The $\mathrm{Al}_{2} \mathrm{O}_{3}$ contents range from 15 to $21 \mathrm{wt} \%$ and the calculated Mg\# numbers from 25 to 68 (Fig. 5d). Sr concentrations vary from 208 to 893 ppm, with low Y (2.2-13 ppm) and $\mathrm{Yb}(0.5-1.5 \mathrm{ppm})$ contents similar to the range observed in typical adakites (Defant and Drummond, 1990). The adakite-like geochemical features are further underlined by their fractionated REE patterns with a mean $(\mathrm{La} / \mathrm{Yb})_{N}$ of 15.2 (Fig. 7c and d), depletions in $\mathrm{Nb}$, $\mathrm{Ta}$ and Ti, enrichments in $\mathrm{U}$ and $\mathrm{K}$, a mildly positive to absent Eu anomaly and high $\mathrm{Sr} / \mathrm{Y}$ and $\mathrm{La} / \mathrm{Yb}$ but low Y and Yb. On the Harker diagrams (Fig. 6), a significant correlation between major and incompatible element ratios vs. $\mathrm{SiO}_{2}$ between the southern and northern intermediate samples could imply that the magmas are connected by magma chamber 


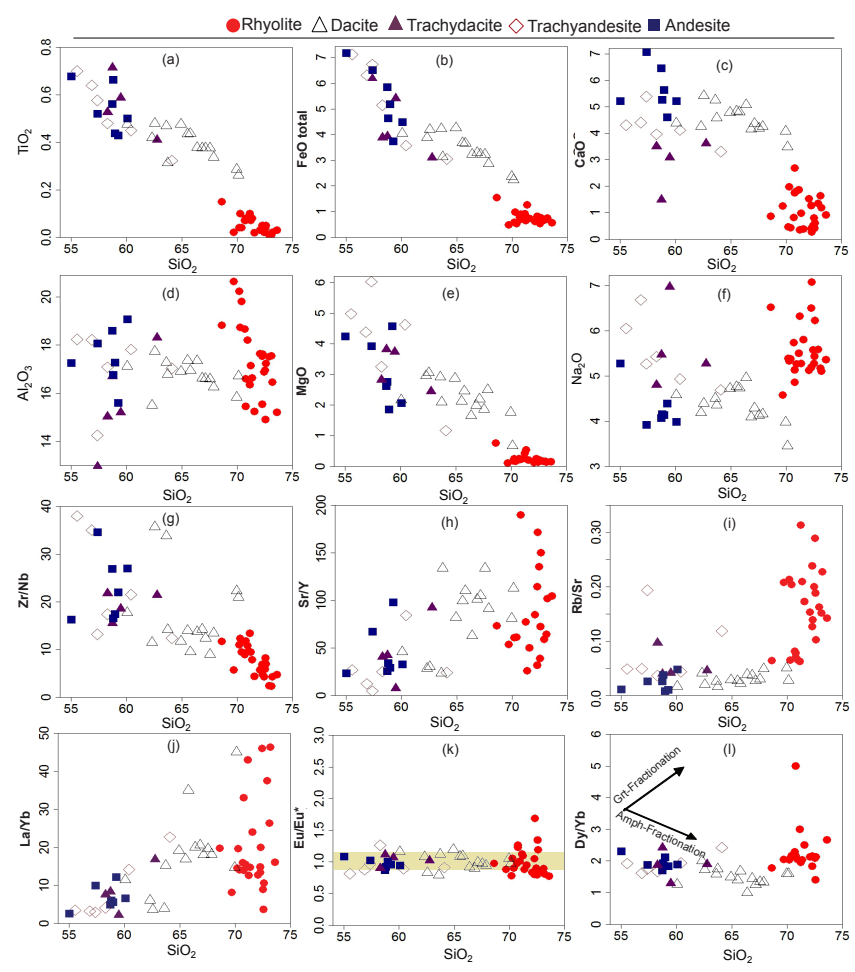

Figure 6. Harker diagrams of the major oxides (wt \%) and incompatible element ratios vs. $\mathrm{SiO}_{2}$ for the studied rocks.

processes, such as fractional crystallization or AFC, likely involving significant amphibole fractionation.

\subsection{Mineral chemistry}

\subsubsection{Amphibole}

Amphibole phenocrysts are found as euhedral crystals with normal zoning in the trachyandesite and dacite samples and mostly as acicular or star-shape crystals in andesite dykes from the northern part of the study area. Selected amphiboles were analyzed for major element compositions. Amphibole stoichiometry and nomenclature follows the recommendations by the International Mineralogical Association (IMA) outlined in Leake et al. (1997), where the $\mathrm{Fe}^{+3} / \mathrm{Fe}^{+2}$ ratio is determined by charge balance after normalization of the major element analyses on the basis of 23 oxygens to 13 cations. This scheme is based on the general chemical formula $\mathrm{A}_{0-1} \mathrm{~B}_{2} \mathrm{C}_{5}^{\mathrm{VI}} T_{8}^{\mathrm{IV}} \mathrm{O}_{22}(\mathrm{OH} ; \mathrm{F} ; \mathrm{Cl})_{2}$. Because the water and halogen contents of the amphiboles are unknown, the amphibole formula is calculated to 23(O). Amphiboles are classified through the number of atoms per formula unit (apfu) of $\mathrm{Ca}$ and $\mathrm{Na}$ in the $\mathrm{B}$ site, (i.e., $\left.(\mathrm{Ca}+\mathrm{Na})_{\mathrm{B}}\right)$ and amphiboles from the northern subvolcanic suite plot in the calcic amphibole field. These amphiboles have Si between 6 and 7 values per formula, characteristic of igneous amphiboles (Leake, 1978). The compositions of the amphiboles from
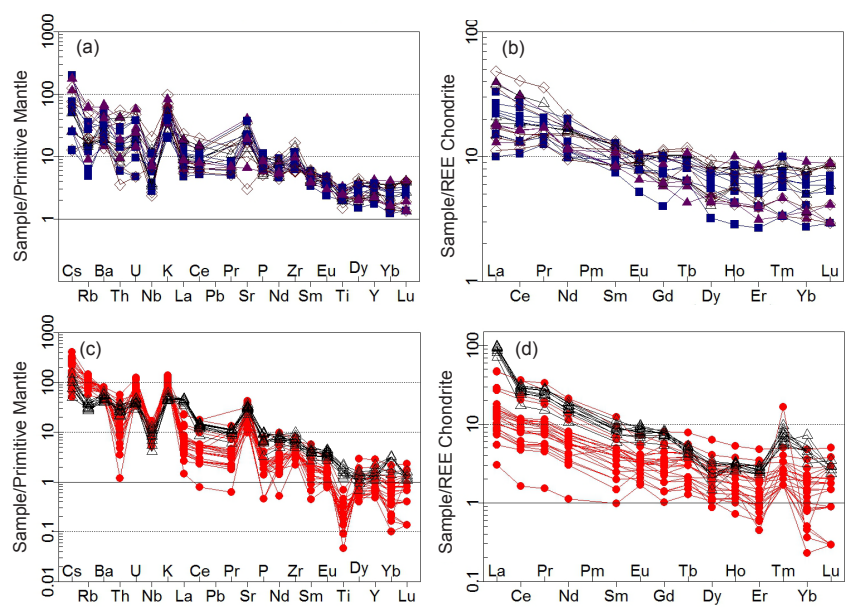

Figure 7. Normalized REE and trace element patterns for the northern (a, b) and southern (c, d) subvolcanic rocks. Primitive-mantle and chondrite data are from Sun and McDonough (1989).

the andesite, trachyandesite, trachydacite and dacite samples are shown in the $\mathrm{Mg} /\left(\mathrm{Mg}+\mathrm{Fe}^{2+}\right)$ vs. Si classification diagram (Fig. 9). The amphiboles from the andesite samples are $\mathrm{Mg}$-hastingsites to tschermakites, those in the trachyandesite and trachydacite samples are tschermakite, and those amphiboles from dacites are mostly magnesiohornblende (Fig. 9ac). Mg-hastingsite can be separated from pargasite by values of $\mathrm{Al}^{\mathrm{VI}}$ and $\mathrm{Fe}^{+3}$ cations per formula; $\mathrm{Al}^{\mathrm{VI}}$ values in hastingsite are less than $\mathrm{Fe}^{+3}$ (Fig. 9b). Calcic amphiboles can be used to distinguish crystals of calc-alkaline liquids from those of alkaline liquids. $\mathrm{K}$ content of calc-alkaline amphibole is consistently lower than that of crystals in equilibrium with alkaline melts (Ridolfi and Renzulli, 2012). According to a plot of ${ }^{\mathrm{A}} \mathrm{K}$ vs. ${ }^{\mathrm{VI}} \mathrm{Al}$ (Fig. 9d), all selected amphiboles are calc-alkaline in nature. A plot of 6-fold $\mathrm{Al}\left(\mathrm{Al}^{\mathrm{VI}}, \mathrm{C}\right.$ site $)$ vs. 4-fold $\mathrm{Al}\left(\mathrm{Al}^{\mathrm{IV}}, T\right.$ site) for amphiboles from all rock suites (Fig. 9e) indicates that $\mathrm{Al}$ preferentially resides in the tetrahedral site, which, together with the negative correlation between $(\mathrm{Na}+\mathrm{K})^{\mathrm{A}}$ vs. Si p.f.u (Fig. 9f), implies the dominance of edenite-type $\left(\mathrm{Na}, \mathrm{K}_{\mathrm{A}}+\mathrm{Al}^{\mathrm{IV}}=\mathrm{Si}^{\mathrm{IV}^{\mathrm{V}}}\right)$ substitution for the presented amphiboles (cf. Murphy et al., 2012).

Although the amphiboles are unzoned in the andesites, simple and oscillatory zoning is present in amphiboles from the trachyandesites and trachydacites. The simple-zoned amphibole phenocrysts are characterized by broad cores that commonly host small subhedral inclusions of Fe-Ti oxides (not shown). The cores of the simple-zoned phenocrysts are tschermakite and show a progressive rimward increase in $\mathrm{Mg}$ that is coupled with decrease in ${ }^{\mathrm{IV}} \mathrm{Al}$ and $(\mathrm{Na}+\mathrm{K})^{\mathrm{A}}$. The oscillatory-zoned amphibole phenocrysts in the dacite and trachydacite samples are illustrated by alternating dark and bright euhedral zones in back-scattered images (Fig. 10a). This zoning is characterized by a tschermakitic core that also commonly hosts small inclusions of Fe-Ti oxides and apatite. The cores of these minerals show a rimward decrease in $\mathrm{Mg}$ 

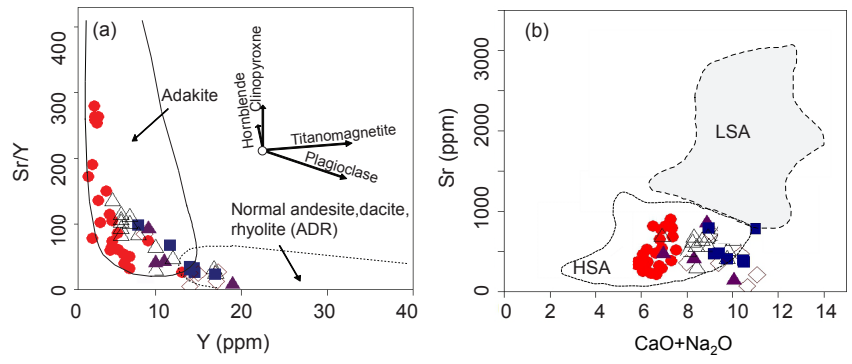

Figure 8. (a) Plot of $\mathrm{Sr} / \mathrm{Y}$ vs. Y for the studied rocks. Fields of adakite and arc-normal rocks are from Petford and Atherton (1996) and Defant and Drummond (1990). (b) Plot of Sr vs. $\mathrm{CaO}+\mathrm{Na}_{2} \mathrm{O}$ (wt \%) showing the chemical differences between low silica adakites (dashed field) and high-silica adakites (dotted field) (after Castillo, 2012).

(from 3.44 in the core to 2.8 cations p.f.u. in the rim) and an increase in $\mathrm{Al}^{\mathrm{IV}}$ (from 1.59 to 1.63 cation p.f.u) and $(\mathrm{Na}+$ $\mathrm{K})^{\mathrm{A}}$ (from 0.30 to 0.41 ). The cores are overgrown by a layer of dark Mg-hornblende and show significantly lower $\mathrm{Al}^{\mathrm{IV}}$ $(1.36)$ and $(\mathrm{Na}+\mathrm{K})^{\mathrm{A}}(0.28)$ compared to the cores. Interval changes in this zone are marked by decreases in $\mathrm{Mg}$ (from 3.17 to 2.62 cations p.f.u) and increases in $\mathrm{Al}^{\mathrm{IV}}$ (from 0.26 to 0.46 p.f.u) and $(\mathrm{Na}+\mathrm{K})^{\mathrm{A}}(0.17-0.47)$ toward the rim. The $\mathrm{Mg}$-hornblende zones then grade into outer rims with ferriantschermakite composition, reflecting normal zoning with a decreasing trend in $\mathrm{Fe}^{+2}$ (from 1 to 0.41 p.f.u), $\mathrm{Al}^{\mathrm{IV}}$ (1.77 to 0.59 p.f.u) and $(\mathrm{Na}+\mathrm{K})^{\mathrm{A}}$ (from 0.43 to 0.33 ) and a very mild increase in $\mathrm{Mg}$ (from 3 to 3.14 cation p.f.u) (Fig. 10b, c).

\subsubsection{Plagioclase}

Plagioclase occurs abundantly together with amphibole in the northern subvolcanic samples as individual phenocrysts, microphenocrysts, and microlites. Although plagioclase crystals commonly range between 0.5 and $3 \mathrm{~mm}$, large phenocrysts up to $7 \mathrm{~mm}$ in length do occur in some dacite samples from the northern part. The southern rhyolite suite comprises plagioclase as phenocrysts and microlites. The composition of plagioclase phenocrysts in the andesite and trachyandesite rocks ranges from $\left(\mathrm{An}_{53} \mathrm{Ab}_{46} \mathrm{Or}_{1}\right)$ to $\left(\mathrm{An}_{70} \mathrm{Ab}_{29} \mathrm{Or}_{1}\right)$ and $\left(\mathrm{An}_{36} \mathrm{Ab}_{62} \mathrm{Or}_{2}\right)$ to $\left(\mathrm{An}_{56} \mathrm{Ab}_{43} \mathrm{Or}_{1}\right)$, respectively. Plagioclase is the volumetrically dominant phenocryst phase in the trachydacite $\left(\mathrm{An}_{31} \mathrm{Ab}_{67} \mathrm{Or}_{2}\right.$ to $\left.\mathrm{An}_{49} \mathrm{Ab}_{51} \mathrm{Or}_{1}\right)$ and dacite $\left(\mathrm{An}_{40} \mathrm{Ab}_{58} \mathrm{Or}_{2}\right.$ to $\left.\mathrm{An}_{24} \mathrm{Ab}_{73} \mathrm{Or}_{3}\right)$ samples, but is rare in the rhyolites $\left(\mathrm{An}_{15} \mathrm{Ab}_{80} \mathrm{Or}_{5}\right.$ to $\mathrm{An}_{8} \mathrm{Ab}_{88} \mathrm{Or}_{4}$ ). Despite some homogeneous plagioclase phenocrysts that occur in the andesites, most of the samples in the northern part exhibit plagioclase with complex zoning of variable types. Plagioclase microlites, in turn, are usually unzoned and have homogeneous compositions or minor normal zoning. Figure 11a shows the compositional spectrum of all plagioclase crystals analyzed in the feldspars compo-
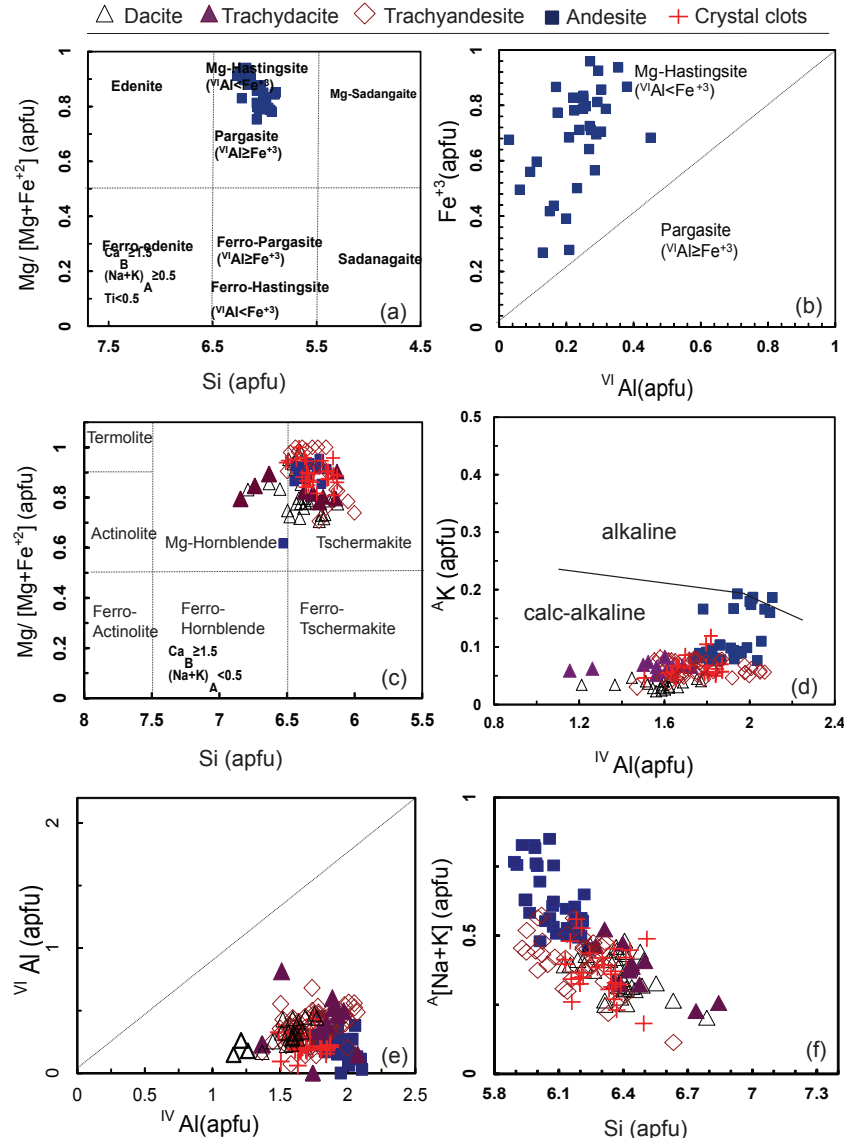

Figure 9. Major element classification diagrams for amphiboles. (a) Amphiboles in the Mg-andesite samples. (b) Amphiboles in andesites with ${ }^{\mathrm{V} 1} \mathrm{Al}<\mathrm{Fe}^{+3}$ fall in the $\mathrm{Mg}$-hastingsite field. (c) Amphiboles in the trachyandesite, trachydacite, dacite samples and amphibole from crystal clots on the $\mathrm{Mg} /\left(\mathrm{Mg}+\mathrm{Fe}^{2+}\right)$ vs. Si classification diagrams (after Leake, 1978, Leake et al., 1997, 2004). (d) ${ }^{A}$ K vs. ${ }^{\mathrm{VI}} \mathrm{Al}$ diagram after Ridolfi and Renzulli (2012) showing our calcic amphiboles in equilibrium with calc-alkaline liquids. (e) ${ }^{\mathrm{V} 1} \mathrm{Al}$ plotted against ${ }^{\mathrm{IV}} \mathrm{Al}$ per formula unit and (f) $(\mathrm{Na}+\mathrm{K}){ }^{\mathrm{A}}$ vs. $\mathrm{Si}$ per formula unit for amphiboles from all samples. Procedure for assigning Al according to Leake (1978) and Leake et al. (2004). Solid black line in (e) indicates slope of 1.

sition triangle. Notably, plagioclase phenocrysts with pronounced sieved textures are preferentially found in dacite rocks (Fig. 11b, c). Two types of primary zoning in plagioclase are dominant and include normal and oscillatory (complex) types:

Normal zoning in plagioclase implies a composition change from calcic to less calcic with progressive growth (Bottinga et al., 1996; L'Heureux, 1997). This type of zoning is seen in a fraction of plagioclase phenocrysts and most microcrystals. It lacks internal dissolution surfaces and the zoned phenocrysts range in composition from $\mathrm{An}_{50}$ to $\mathrm{An}_{39}$ and likely reflect periods of stable growth from progressively evolving melts that became depleted in $\mathrm{Ca}$. 

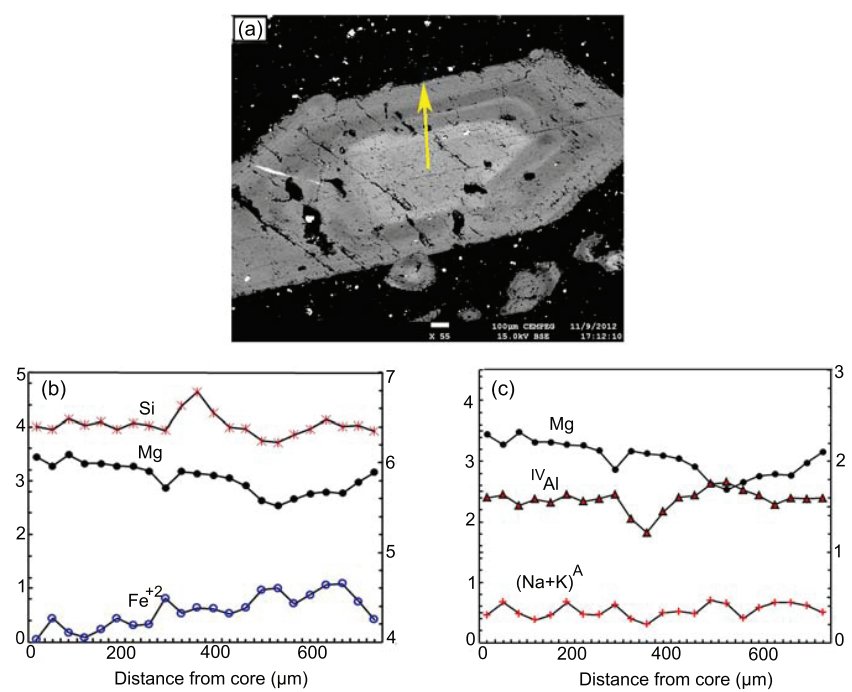

Figure 10. (a) Back-scatter electron microprobe image of a representative amphibole phenocryst from a trachydacite sample that comprises distinct alternating dark and light zones. (b) and (c) Major element traverses in multiple-zoned amphibole phenocryst from (a). Arrow indicates position of rim to core traverse. Scale bars represent $100 \mu \mathrm{m}$.

Oscillatory zoning is also present in a fraction of feldspars and consists of alternating thin growth zones with variable An contents (cf. Allegre et al., 1981; Bottinga et al., 1996; L'Heureux, 1997). In our samples, neighboring zones show an abrupt increase in An (up to $15 \mathrm{~mol} \%$ ). Phenocrysts have typically euhedral to subhedral shapes. Oscillatory types appear particularly in trachydacite, dacite and in one of the rhyolite samples. Characteristically, the cores are marked by a slight increase in $X_{\mathrm{An}}$ (e.g., from $\mathrm{An}_{29}$ to $\mathrm{An}_{39}$ ) followed by several zones with markedly higher anorthite contents $\left(\mathrm{An}_{46-55}\right)$ (Fig. 11b, d). These An-rich compositions are then usually followed by steep normal zoning. Reverse zoned outer margins $(\sim 100 \mu \mathrm{m})$ often follow and are characterized by an overall increase in $X_{\mathrm{An}}$ (e.g., from $\mathrm{An}_{39}$ to $\left.\mathrm{An}_{44}\right)$. Simple resorption has taken place at some of the internal boundaries, as marked by wavy truncated internal surfaces.

Sieved texture plagioclase phenocrysts are frequently found in trachydacites and dacites and generally show resorbed cores and oscillatory-zoned overgrowth rims (Fig. 11 c, e). Broad patchy cores are usually albite $\left(\mathrm{An}_{24-34)}\right.$ and are mantled by more An-rich $\left(\mathrm{An}_{36-47}\right)$ overgrowth rims. This increase in $X_{\mathrm{An}}$ is accompanied by an increase in Fe and usually follows a partial dissolution event, which is symptomatic of magma mixing with a more mafic melt (cf. Troll and Schmincke 2002). (a)
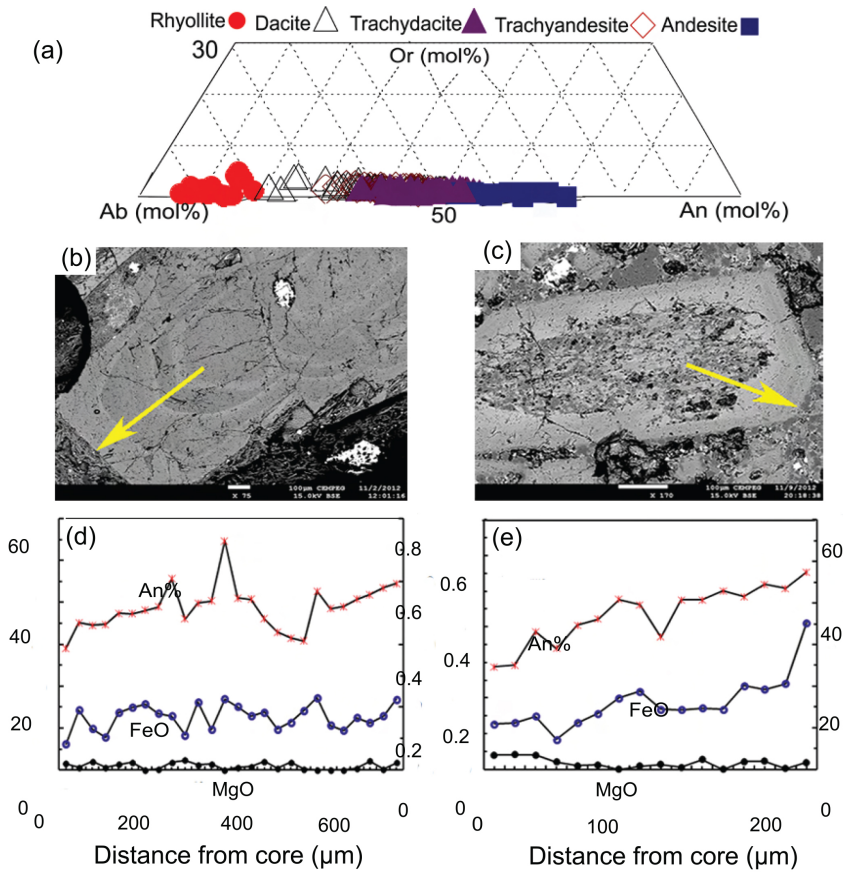

Figure 11. (a) Composition of all analyzed plagioclase data points $(n=212)$ in the feldspars composition triangle. Plagioclase composition in the samples of the northern sector vary between $\mathrm{An}_{20}$ and $\mathrm{An}_{70}$. Plagioclase in rhyolites from the south part range from $\mathrm{An}_{20}$ to $\mathrm{An}_{8}$. The BSE images of selected plagioclase phenocrysts show (b) oscillatory-zoned plagioclase with an abrupt increase in An contents (up to $15 \mathrm{~mol} \%$ ) toward the rim and (c) sieve-textured plagioclase mantled by high An rim. (d) and (e) Zoning profiles showing variations in $X_{\mathrm{An}}$ and $\mathrm{MgO}$ and $\mathrm{FeO}$ for the oscillatoryzoned plagioclase and the sieve-textured plagioclase in (b) and (c), respectively. Yellow arrows indicate core to rim profile.

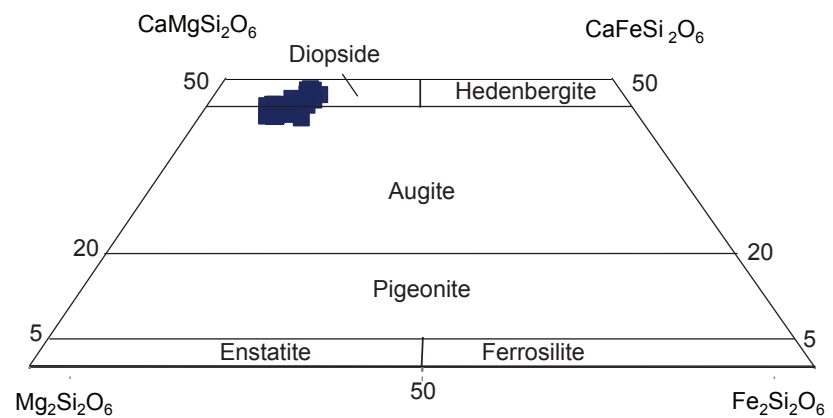

Figure 12. Composition of clinopyroxene (no. 29). All clinopyroxene data plots in the diopside field.

\subsubsection{Clinopyroxene}

Clinopyroxene crystals are mostly euhedral and are only found in the high Mg-andesite where they occur together with Mg-hastingsite. The mineral chemistry of clinopyroxene is very homogenous, and all the analyzed specimens plot in the diopside field $\left(X_{\mathrm{Mg}}\right.$ mean value $=0.8$, with 
clinopyroxene formula calculated on the basis of 6 oxygen; Fig. 12). They exhibit no clear petrographic indicators of being out of equilibrium with andesitic host rock, as they are commonly euhedral and lack strong compositional zoning. Representative clinopyroxene compositions are provided in Table 4.

\subsection{Temperature and pressure from amphibole thermobarometry}

High Mg-hastingsites from the andesite samples yielded temperatures of 908 to $992^{\circ} \mathrm{C}( \pm 23.5)$, while tschermakitic amphiboles from the trachyandesite and trachydacite samples range from 868 to $960^{\circ} \mathrm{C}$ and from 858 to $946^{\circ} \mathrm{C}$, respectively (Fig. 13a). Magnesian hornblendes from the dacite samples range from 836 to $873{ }^{\circ} \mathrm{C}$ and estimated temperatures for amphiboles in the clots range between 874 and $974{ }^{\circ} \mathrm{C}$.

Amphiboles from andesites yield pressures of on average $556 \mathrm{MPa}(820-349)$ (Fig. 13a). The highest crystallization pressures (820-700 MPa) correspond to the Mg-hastingsites from the basaltic andesite. Average pressure estimates of $\sim 370 \mathrm{MPa}$ (714-246) for tschermakites in trachyandesites and $\sim 320 \mathrm{MPa}(388-268)$ in trachydacites are derived. Mghornblendes in dacites yield pressure of $\sim 190 \mathrm{MPa}$ (226145), while tschermakites from crystal clots gave an average pressure of $\sim 395 \mathrm{MPa}$ (780-217). To reconstruct the plumbing system, we used the density of the ophiolite complex $\left(3.0 \mathrm{~g} \mathrm{~cm}^{3}\right)$ and also applied this value to the sub-ophiolite units (see Discussion).

The oxygen fugacity of a crystallizing magma is reflected in the $\mathrm{Mg}$ content of resulting amphiboles and values of $\log \left(f \mathrm{O}_{2}\right)$ for Mg-hastingsites in andesites range from -10 to -8.9 (Fig. 13b). Values of $\log \left(f \mathrm{O}_{2}\right)$ for tschermakites from trachyandesites and trachydacites range from -11 to -9.5 and -11.0 to -9.8 , respectively. $\mathrm{Mg}$-hornblendes of dacites show $\log \left(f \mathrm{O}_{2}\right)$ from -12.1 to -10.9 (Fig. 13b). Tschermakites from crystal clots have a value of $\log \left(f \mathrm{O}_{2}\right)$ similar to trachyandesitic samples ranging between -10.4 and -9.3 (Fig. 13b). Oxygen fugacity generally increases from high $P-T$ magnesiohastingsite (avg. $700 \mathrm{MPa}, 990^{\circ} \mathrm{C}$ ) to lower $P-T$ magnesiohornblende (avg. $190 \mathrm{MPa}, 840^{\circ} \mathrm{C}$ ), consistent with the compositional variations known for calcalkaline magmas from experiments (Gill, 1981; Martel et al., 1999; Müntener et al., 2001; Behrens and Gaillard, 2006).

A diagram of $\mathrm{H}_{2} \mathrm{O}_{\text {melt }}-T$ of the amphibole suite is given in Fig. 13c, where the stability field of experimental amphiboles is outlined by a dotted curve. The experimental amphiboles comprise crystals with $\mathrm{Al} \# \leq 0.21$ that were synthesized in equilibrium with melts overlapping the main $\mathrm{Al}_{2} \mathrm{O}_{3}$ vs. $\mathrm{SiO}_{2}$ pattern of extrusive rocks and glasses (cf. Ridolfi et al., 2010). All studied amphibole samples fall within the range of the experimentally determined equilibrium amphiboles with low-Al\# $(<0.21)$ (Ridolfi et al., 2010). This Al-value is, in turn, in equilibrium with $\mathrm{H}_{2} \mathrm{O}_{\text {melt }}$ values of 3.7 to $8.2 \mathrm{wt} \%$
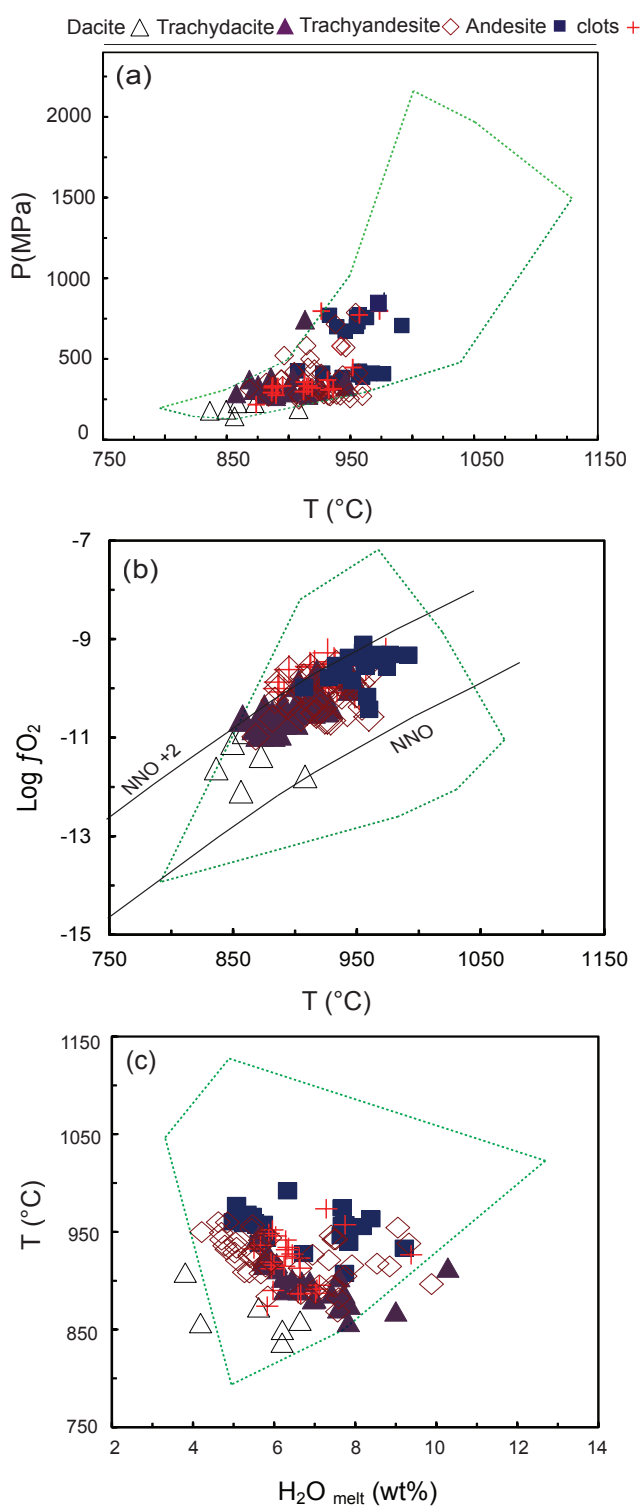

Figure 13. (a) $P-T$ diagram for calcic experimental amphiboles after Ridolfi and Renzulli (2012) with low uncertainties $\left(T \pm 23.5^{\circ} \mathrm{C}\right.$, $P \pm 11.5 \%$ ). Our amphiboles plot in the field of experimentally reproduced amphiboles (after Ridolfi and Renzulli 2012). (b) Log ( $f \mathrm{O}_{2}$ )- $T$ and (c) $T-\mathrm{H}_{2} \mathrm{O}_{\text {melt }}$ diagrams for the studied amphiboles as obtained by amphibole thermobarometry after Ridolfi and Renzulli (2012). This method indicates typical uncertainties for $\log$ $f \mathrm{O}_{2}$ errors $\left( \pm 0.2 \log\right.$ unit) and $\mathrm{H}_{2} \mathrm{O}_{\text {melt }}( \pm 0.8 \mathrm{wt} \%)$. The NNO and NNO +2 curves are from O'Neill and Pownceby (1993).

$( \pm 0.5)$ (cf. Ridolfi and Renzalli, 2012), which agrees with the $\mathrm{H}_{2} \mathrm{O}$ values known in calc-alkaline magmatic suites (e.g., Gill, 1981; Martel et al. 1999). The $\mathrm{H}_{2} \mathrm{O}_{\text {melt }}$ contents obtained from Mg-hastingsites range between 5 and $8.3 \mathrm{wt} \%$ $( \pm 0.5)$, while tschermakite and $\mathrm{Mg}$-hornblende yield 4.2 to 10.3 and 5 to $7 \mathrm{wt} \%( \pm 0.5)$ melt $-\mathrm{H}_{2} \mathrm{O}$, respectively. Tscher- 
Andesite $\boldsymbol{\Delta}$ Trachydacite/trachyandesite $\triangle$ Dacite Rhyolite
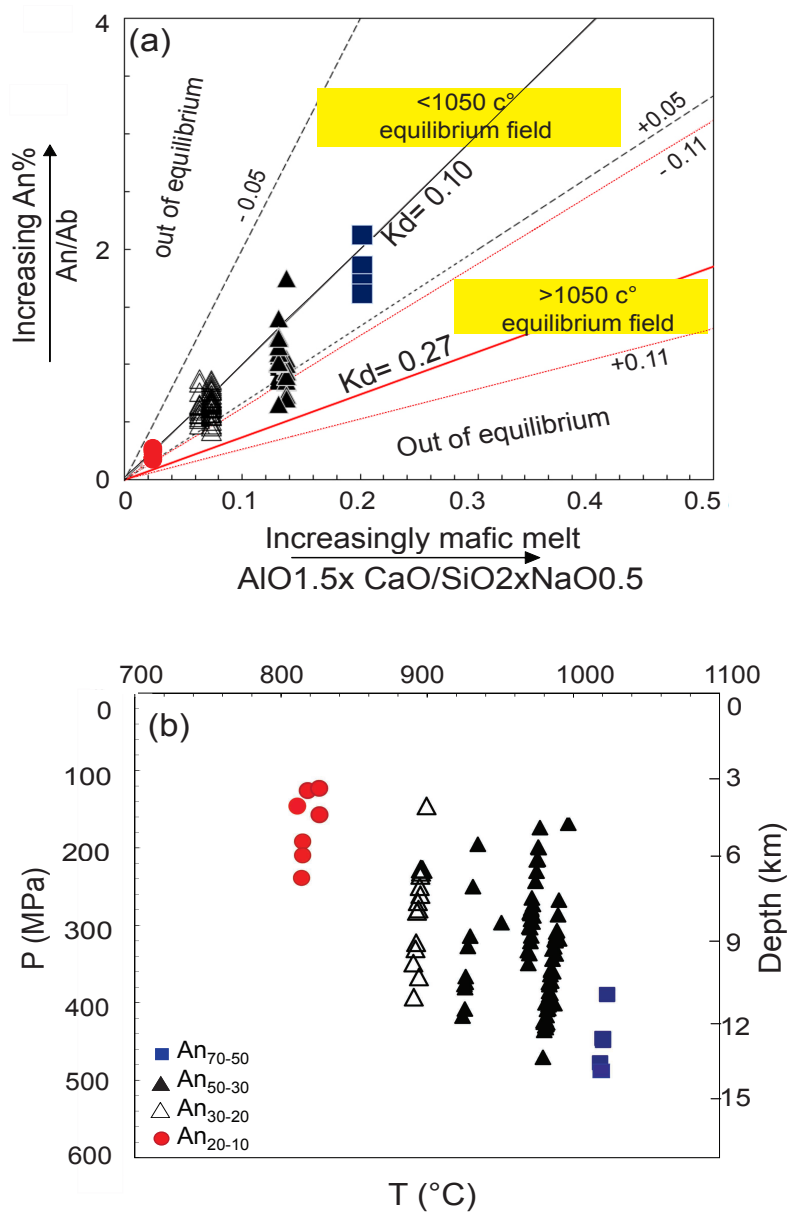

Figure 14. (a) Equilibrium test for plagioclase and four possible melts. The andesite samples appear to be in equilibrium with high anorthite plagioclase $\left(\mathrm{An}_{70-50}\right)$, while the trachyandesite/trachydacite and dacite are in equilibrium with $\left(\mathrm{An}_{50-30}\right)$ and $\left(\mathrm{An}_{30-20}\right)$, respectively. Rhyolite, in turn, is in equilibrium with low anorthite plagioclase $\left(\mathrm{An}_{20-10}\right)$. (b) Results of plagioclase-melt thermobarometry after (Putirka, 2008). SEE for the plagioclase-melt thermobarometer are $\pm 36^{\circ} \mathrm{C}$ and $\pm 247 \mathrm{MPa}$.

makitic clots suggest corresponding $\mathrm{H}_{2} \mathrm{O}_{\text {melt }}$ values between 5.5 to $9.3 \mathrm{wt} \%( \pm 0.5)$.

\subsection{Pressure estimate from plagioclase-melt thermobarometry}

To test the results of the amphibole thermobarometry, the plagioclase thermobarometer of Putirka (2008), calibrated for hydrous systems, was applied. Standard error of estimation (SEE) for the plagioclase-melt thermobarometer is $\pm 36^{\circ} \mathrm{C}$ and $\pm 247 \mathrm{MPa}$ (Putirka, 2008). The Kd [Ab-An] equilibrium test shows that $\mathrm{An}_{50-70}$ is in equilibrium with the whole rock composition of the andesites and these plagioclase-melt pairs record pressures between $\sim 470$ and $335 \mathrm{MPa}$ (Fig. 14a, b). The lower-anorthite plagioclase $\left(\mathrm{An}_{50-30}\right.$ and $\left.\mathrm{An}_{30-20}\right)$ shows disequilibrium with the andesite nominal melt, but yields equilibrium with the available trachydacite and dacite compositions, respectively. Plagioclases with $\mathrm{An}_{50-30}$ record pressures between $\sim 435$ and $190 \mathrm{MPa}$ and plagioclase with $\mathrm{An}_{30-20}$ records between $\sim 390$ and $130 \mathrm{MPa}$ (Fig. 14a, b). Plagioclase in the southern rhyolites $\left(\mathrm{An}_{20-10}\right)$ yield pressures between $\sim 275$ and $110 \mathrm{MPa}$. The results of the plagioclase-melt thermobarometer record overall mid- to shallow crustal magma storage (468-110 MPa), thus broadly overlapping with the amphibole thermobarometry results.

\subsection{Pressure estimate from clinopyroxene-melt barometry}

Following equilibrium testing between clinopyroxene and available mafic whole rocks as the nominal melt (see Methods), pressure estimates were determined. The selected clinopyroxenes (sample N-1, Fig. 15a, b) satisfy equilibrium conditions with the analyzed andesite whole rock and, using clinopyroxene-melt barometry after Putirka (2008, eqn $32 \mathrm{c}$ ), average pressures of $\sim 600 \mathrm{MPa}$ (730 to 510) are retrieved (Fig. 15c). These results are higher than the results from plagioclase-melt barometry but overlap with pressures of the deeper fraction of amphiboles in these andesites (see above; Fig. 13a).

\section{Discussion}

The Cretaceous to Paleocene Sabzevar ophiolitic zone in present-day Iran formed during northward subduction of the Tethyan oceanic crust beneath the eastern Alborz (Binalud) plate. Post-ophiolite subvolcanic rocks are widely distributed in the northern and southern parts of this zone and show characteristic subduction-related trace-elements signatures, such as negative $\mathrm{Nb}, \mathrm{P}$ and $\mathrm{Ti}$ anomalies coupled with enriched LILE elements. The northern post-ophiolite magmatic rocks show a broad compositional range, from andesite to dacite, while the southern rocks are exclusively rhyolite and rhyodacite in composition (Fig. 5a). All these post-ophiolite rocks fall within the adakite field on commonly used discrimination diagrams, such as $\mathrm{Sr} / \mathrm{Y}$ vs. Y (Fig. 8a). Some of their adakitic affinities include the relative enrichment of $\mathrm{Sr}$, depletion of $\mathrm{Yb}$ and $\mathrm{Y}$ and the negligible or absent Eu anomalies (Fig. 6k). Adakites have been originally considered as products from partial melting of subducting metabasaltic source materials (Defant and Drummond, 1990), while later work considered adakites to potentially form from lower crustal melting also (e.g., Castillo, 2012).

To help constrain the way adakites form, we first discuss the magma composition and plumbing of the northern adakites suite. These illustrate negative correlations of $\mathrm{TiO}_{2}$, $\mathrm{FeO}_{\text {total }}, \mathrm{MgO}$ and $\mathrm{CaO}$ vs. $\mathrm{SiO}_{2}$ in the binary diagrams (Fig. 6), indicating crystallization-controlled differentiation 

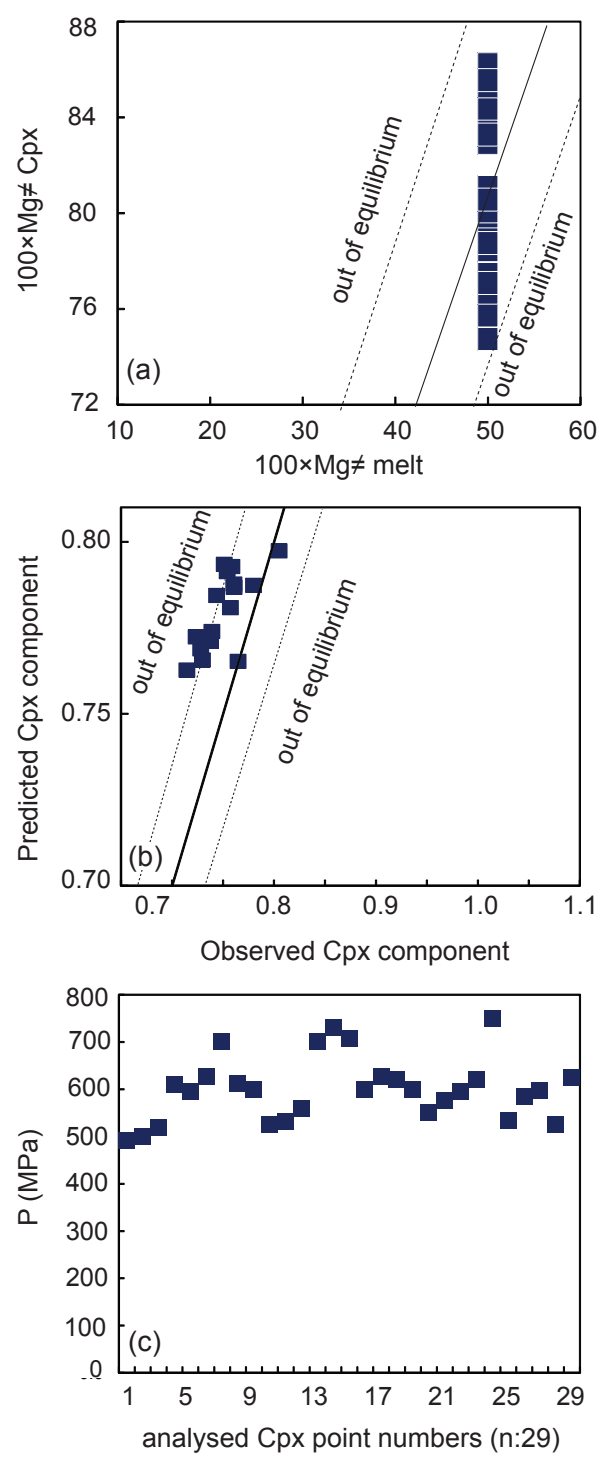

Figure 15. (a) Test for equilibrium using the $\mathrm{Kd}[\mathrm{FeMg}]$ between clinopyroxene and nominal melt (basaltic andesite sample [no. $\mathrm{N}-1]$ ). The result shows $\mathrm{Kd}[\mathrm{FeMg}]$ values close to the ideal of 0.27 (Putirka, 2008). (b) Test for equilibrium using predicted vs. observed clinopyroxene components of diopside + hedenbergite derived using the nominal equilibrium melt (basaltic andesite dyke). Pressure calculated for selected clinopyroxene using clinopyroxene-melt barometry after Putirka (2008).

trends. Lower contents of MREEs (e.g., $\mathrm{Tb}=0.1 \mathrm{ppm}$ ) and $\mathrm{Y}(3.5-8 \mathrm{ppm})$ as well as decreasing in Dy / Yb with differentiation (increasing $\mathrm{SiO}_{2}$ ) and strong increasing in $\mathrm{Zr} / \mathrm{Sm}$ (73-89 ppm), Zr (88-186 ppm) in more evolved rocks (e.g., dacites) suggest extensive fractionation of amphibole (e.g., Davidson et al.; 2007) in agreement with its occurrence as phenocrysts in andesite to dacite samples. Prolonged amphibole fractionation is also supported by the presence of amphibole and clinopyroxene phenocrysts in the most primitive Mg-andesite that simultaneously lacks plagioclase as a phenocryst phase. The compositional variations of the amphibole reflect changes in $T, P, \mathrm{pH}_{2} \mathrm{O}, f \mathrm{O}_{2}$ and melt composition (e.g., Rooney et al., 2010); intense fractionation of amphibole will increase the $\mathrm{Sr} / \mathrm{Y}$ ratios and decrease the $\mathrm{Y}$ concentrations in the resulting melt (Foley et al., 2013), driving compositions to that of typical adakite magmas. Crystal clots composed of amphibole have been suggested to represent clusters of phenocrysts (Garcia and Jacobson, 1979), the products of amphibole breakdown (Stewart, 1975), cooler wall-rock material (Humphreys et al., 2009), disrupted cumulates or crystal mush zones (e.g., Seeman, 2000; Chiaradia et al., 2011), or xenoliths (Chiaradia et al., 2009). Our investigation shows that the mineral compositions and the crystallization conditions ( $T, P$ and $f \mathrm{O}_{2}$ ) of the crystal clots overlap with the phenocryst assemblage of the host-rock, implying that the clots in the present system are clusters of microphenocrysts that crystallized from the magma chamber and thus represent the semi-solidified portions of a dynamic plumbing system.

The core to rim variations in the simple-zoned amphibole phenocrysts show an overall rimward decrease in $\mathrm{Al}^{\mathrm{IV}}$, $(\mathrm{Na}+\mathrm{K})^{\mathrm{A}}$ and $\mathrm{Fe}^{+2}$ accompanied by an increase in $X_{\mathrm{Mg}}$. This pattern can be explained by gradual cooling during crystallization (e.g., Humphreys et al., 2006), where composition of the amphibole has likely been modified in response to changing melt composition controlled by plagioclase crystallization (cf. Holland and Blundy, 1994). For example, slight increases in melt- $\mathrm{H}_{2} \mathrm{O}$ result in dissolution and crystallization of An-rich compositions (Housh and Luhr, 1991). Although normal-zoned plagioclases with small-amplitude variation are probably a result of minor local disequilibrium or small-scale pressure and temperature changes (Pearce and Kolisnik, 1990), the occurrence of disequilibrium phenocryst composition and textures such as oscillatory-zoned amphibole and plagioclase and sieved textured plagioclase cannot be explained by simple closed system fractionation alone.

Oscillatory and especially complex zoning in plagioclase is often marked by resorption surfaces presented by rounded or wavy truncated interfaces (e.g., Fig. 11b), which are attributed to large-scale changes in temperature, pressure, melt- $\mathrm{H}_{2} \mathrm{O}$ content and/or melt composition and frequently associated with magma recharge or mixing events. Pressure changes that exceed several Pascal are already capable of changing plagioclase composition (Nelson and Montana, 1992), which implies that the broad diffuse cores of the simple-zoned amphibole and oscillatory-zoned plagioclase phenocrysts then likely reflect crystallization under stable magma chamber conditions over longer periods of time (e.g., Foley et al., 2013). However, the presence of several successive zones with markedly increased An content in oscillatory-zoned plagioclase in the dacites and trachydacites (up to $15 \mathrm{~mol} \%$ ) likely reflects magma mixing and incoming batches of more mafic melts, in line with sieve-textured plagioclase phenocrysts that show An-rich overgrowths rims and embayments in quartz (when present). When hot and 
more mafic magma intrudes a colder, more differentiated reservoir, crystals near the mixing interface are re-melted and produce sieve textures and embayments (e.g., Donaldson and Henderson, 1988; Tepley et al., 2001; Andrews et al., 2008) but ultimately cause more anorthitic plagioclase to grow, e.g., onto the remaining plagioclase fragments (e.g., Troll et al., 2004). This interpretation is supported by sieved textured plagioclase cores in dacites that are overgrown by rims with elevated $X_{\mathrm{An}}\left(\mathrm{An}_{44}\right)$ and $\mathrm{Mg}$ and Fe contents compared to their core $(\sim$ An29).

The dacite/rhyolite domes in the southern part of the Sabzevar zone have high $\mathrm{Sr} / \mathrm{Y}$ and $\mathrm{La} / \mathrm{Yb}$ ratios but low $\mathrm{Y}(2.2-13 \mathrm{ppm})$ and $\mathrm{Yb}(0.5-1.5 \mathrm{ppm})$ contents, resembling typical adakites as defined by Defant and Drummond (1990). However, the $\mathrm{Sr}$ contents (209-377.5 ppm) for 13 of the 25 rhyolite samples are not as high as known from typical adakites ( $>400 \mathrm{ppm}$ ). Notably, oceanic slab-derived adakites are generally metaluminous, whereas the southern adakite rocks are metaluminous to peraluminous with low $\mathrm{Mg} \#$ (Fig. 5d) and so differ from delamination-derived adakites. Compared to the adakite rocks derived from partial melting of subducted oceanic crust, most samples of southern domes are potassium-rich $\left(\mathrm{K}_{2} \mathrm{O}\right.$ up to $\left.7 \mathrm{wt} \%\right)$, with low A/NK ratios, and are thus akin to adakites of lower-crustal derivation (e.g., Wang et al., 2012) (Fig. 5 c), which may point to a thickened crust in the region. In contrast, a significant correlation between major and incompatible element ratios vs. $\mathrm{SiO}_{2}$ between the southern high-silica samples and the northern intermediate rocks strengthen the hypothesis that the southern adakite samples are derived from the northern intermediate melts through continued magma chamber processes, e.g., assimilation and fractional crystallization. A coevolution of northern intermediate magmas and southern felsic rocks is also supported by a decrease in the $\mathrm{Dy} / \mathrm{Yb}$ ratios vs. $\mathrm{SiO}_{2}$ (Fig. 61). This implies that the northern intermediate magma experienced intense amphibole fractionation, which in turn will have helped to generate the high- silica adakitelike magmatism in the southern part. In contrast, Rossetti et al. (2014) proposed wet amphibolite melting during subduction, followed by magma differentiation and high-pressure amphibole fractionation of pristine slab melts, for the genesis of Soltanabad adakite suites in the NE Sabzevar (east of our southern domes). However, considering the peraluminous character of the southern suite, an open magmatic system involving AFC processes in the magma chamber, in addition to pure crystal fractionation, cannot be excluded, but will have to await isotope approaches on these rock suites in the future.

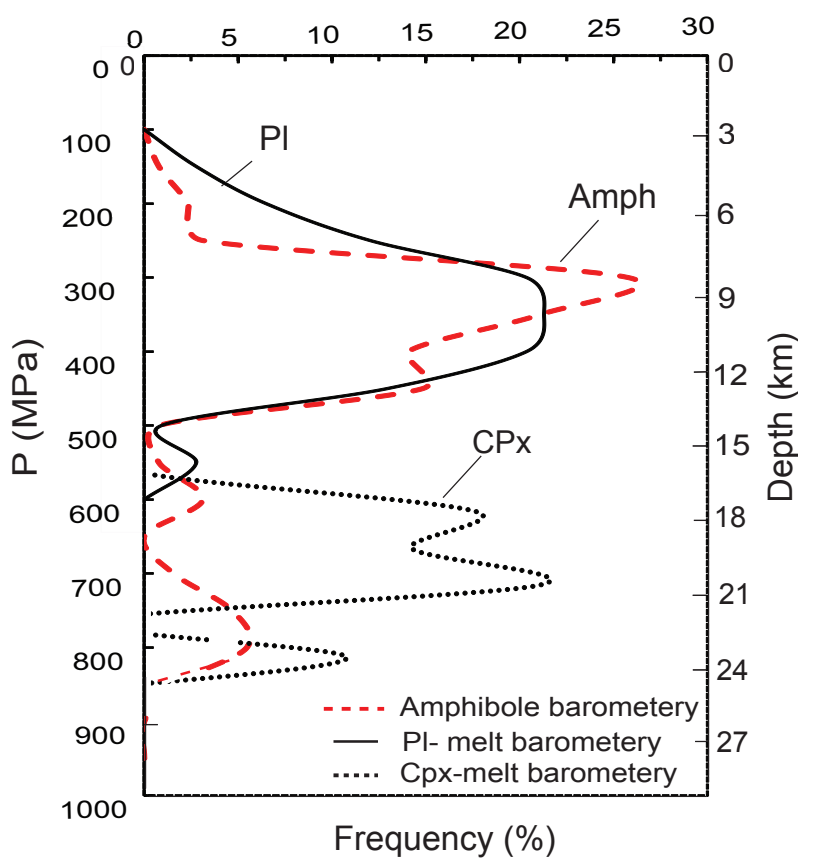

Figure 16. A comparison of the results of amphibole, plagioclasemelt and clinopyroxene-melt barometries that indicate two distinct magma storage regions in the crust, one around a depth of $\sim 6-9 \mathrm{~km}$ and the other at $\sim 18-27 \mathrm{~km}$ depth.

\section{The magma plumbing system}

Our amphibole, plagioclase-melt thermobarometry and clinopyroxene-melt barometry on the northern adakite rocks offer two distinct sets of pressures and temperatures, which indicates two separate levels of major crystallization and thus magma storage ( $\sim 750$ and $\sim 350 \mathrm{MPa}$; Fig. 16$)$. Amphibole formed at both levels, i.e., at pressures of 800 to 700 and 450 to $350 \mathrm{MPa}$, while the majority of plagioclase crystallized in a pressure range of 450 to $300 \mathrm{MPa}$. Little is known about structure of the crust beneath the Sabzevar ophiolitic zone; however, the crust-mantle boundary beneath northeast Iran and central Iran imaged by Motaghi et al. (2012) shows a strong variation of Moho depth from $35 \mathrm{~km}$ under central Iran to $55 \mathrm{~km}$ beneath NE Iran. Following this model and that of Dehghani et al. (1983), we assume the Moho in the study region to be at $\sim 45 \mathrm{~km}$ depth. Therefore, the $\mathrm{Mg}$ hastingsites in the northern part (from Mg-andesite) record a mid- to lower crustal pressure (avg. $\sim 700 \mathrm{MPa}$ ). In contrast, the other amphiboles (tschermakites and Mg-hornblendes) and plagioclases formed during a later stage of crystallization at a shallower level ( $\sim 300 \mathrm{MPa})$. The absence of plagioclase in the $\mathrm{Mg}$-andesite might indicate high water content in the magma source because the plagioclase is unstable under high water pressure (Wang et al., 2012). Dissolved water may have been $\sim 5.5 \mathrm{wt} \%$ in the magma source when hornblende and clinopyroxene formed as phenocrysts, likely too hydrous for plagioclase. However, the matrix is composed 

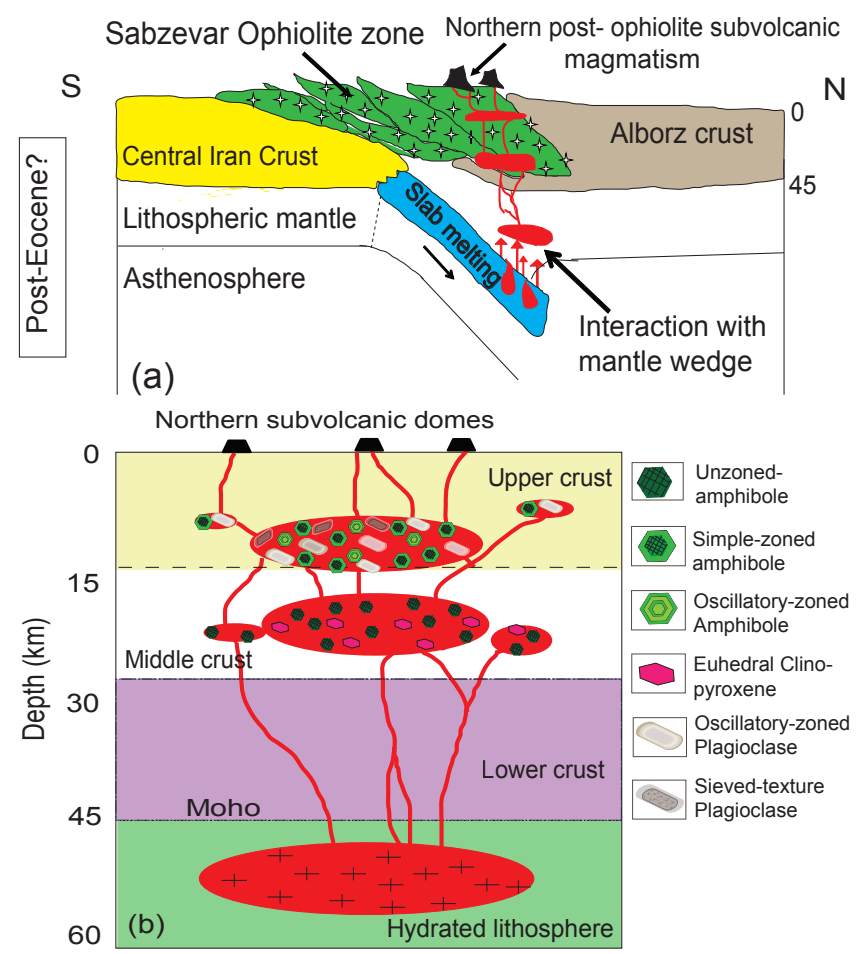

Figure 17. (a) Tectonic framework illustrating northward subduction of Sabzevar oceanic crust (eastern branch of Neotethys) beneath the eastern Alborz zone. (b) Schematic illustration of the magma plumbing system for subvolcanic adakite-like rocks in the northern part of the Sabzevar belt based on the derived thermobarometric data.

of plagioclase with anorthite percent up to $70 \%$. The presence of high An plagioclases in the matrix is also consistent with the inference of a deeper magma source with high water content, based on experimental evidence and plagioclase stability (e.g., Sisson and Grove, 1993; Ramos et al., 2005). Therefore, the Mg-andesite dyke was likely derived from a mid-crustal water-rich mafic magma (Fig. 17a, b). A significant mid- to lower crustal magma storage region is also supported by our clinopyroxene-melt barometry that shows pressures of $\sim 550$ to $700 \mathrm{MPa}$ for clinopyroxenes from $\mathrm{Mg}$ andesite.

The much more abundant medium-anorthite plagioclase phenocrysts $\left(\mathrm{An}_{53}-30\right)$, in equilibrium with a trachyandesite and trachydacite compositions, in turn formed in the upper crust (equal to $300 \mathrm{MPa}$ pressure in average), in agreement with an upper storage region indicated by amphibole barometry (Figs. 16, 17b). Fractional crystallization of amphibole from parental magma in the mid- to lower crust thus likely led to evolved magmas (e.g., trachydacite) in the shallower levels and documents a lively crustal evolution for the samples in question. Plagioclase phenocrysts that display sieve textured cores with an oscillatory-zoned overgrowth provide evidence for hotter mafic magma recharge and subsequent mixing processes, while mineral compositional trends also suggest crystal fractionation.

According to Chaussard and Amelung (2014), arcs with young and thin, ideally sedimentary crusts are more probable to develop shallow magma reservoirs (e.g., 1-3 km below the surface) than arcs with old and thick crusts. Although local effects like crustal heterogeneities such as fractures or sediment layering likely exert an additional control on the depths of magma storage, the shallow reservoir defined for our rock suites $(300 \mathrm{MPa} ; \sim 6 \mathrm{~km}$ ) lies somewhat deeper than the top $3 \mathrm{~km}$ of the crust, which likely relates to the thicker crust in the region $(\mathrm{ca} 45 \mathrm{~km})$ and the dominantly crystalline character of the ophiolitic basement.

\section{Conclusions}

The main conclusions of this study may be summarized as follows:

1. In the northern part of the Sabzevar ophiolitic zone (NE Iran), numerous post-ophiolite subvolcanic domes and dykes of Mg-andesite, trachyandesite, trachydacite and dacite compositions were intruded. In the southern part of the Sabzevar belt, post-ophiolite domes of dacite/rhyolite composition are exposed. Based on the whole rock geochemical features, the northern and southern post-ophiolite rocks have adakite-like affinities. The northern suite is calc-alkaline and metaluminous in nature, while the most southern samples are high-K calc-alkaline and metaluminous to peraluminous.

2. All selected amphiboles from northern samples are low$\mathrm{Al} \#(<0.21)$ and are found to be in equilibrium with high $\mathrm{H}_{2} \mathrm{O}_{\text {melt }}$ values of 4.2 to $10.3 \mathrm{wt} \%( \pm 0.5)$, as demonstrated in Sect. 4.4, consistent with values assumed for 'wet' primitive calc-alkaline magma suites.

3. For the northern samples, the obtained $T$ (992$\left.836^{\circ} \mathrm{C} \pm 23.5\right)$ and $P(820-145 \mathrm{MPa})$ ranges, based on amphibole thermobarometery, record two distinct magma storage regions or levels. The Mg-hastingsite in andesite records mid- to lower crustal pressures $(\sim 700$ $900 \mathrm{MPa})$ that are in line with results from pyroxenemelt barometry. The other amphiboles show a shallow magma storage level equal to pressure of $300 \mathrm{MPa}$ which is, in turn, supported by plagioclase-melt barometry results.

4. The presence of amphibole and clinopyroxene without plagioclase phenocryst in $\mathrm{Mg}$-andesite and the existence of amphibole clots in trachyandesites emphasize that fractionation of amphibole from high $\mathrm{H}_{2} \mathrm{O}$-magma was an important process in producing the diverse range of post-ophiolite rocks observed in the northern sector. 
5. Our textural study documents that mafic magma recharge was driving the evolution of magmatic differentiation and disequilibrium features such as complex zoning and sieved textures in plagioclase, embayed quartz and zoned amphibole with high $\mathrm{Mg} \#$ in the outer margin and suggests that conditions changed for hotter and variably high $f \mathrm{O}_{2}$ conditions due to magmatic replenishment.
6. Selected plagioclases from southern rhyolites $\left(\mathrm{An}_{8-15}\right)$ show crystallization pressures between 273 and $110 \mathrm{MPa}$, implying a shallow upper crustal magma storage region for the southern sector also. According to these geochemical characteristics, we propose the southern silica-rich peraluminous and high-K adakitelike rocks have been produced by differentiation of northern melts through amphibole fractionation and possibly associated crustal assimilation (e.g., AFC) during upper crustal residence. 


\section{Appendix A}

$P-T$ conditions of selected minerals were obtained using amphibole thermobarometry, plagioclase-liquid thermobarometry and clinopyroxene-liquid barometry. Instructions for the equations which are used for the amphibole thermobarometry are given by Ridolfi and Renzulli (2012) in detail (Eq. 1-12, according to instruction and suggestion for using the equations). For plagioclase-liquid thermobarometry after Putirka (2008), $T$ and $P$ were obtained by Eqs. (A1) and (A2), respectively:

$$
\begin{aligned}
& \frac{10^{4}}{T(\mathrm{~K})}=6.12+0.257 \ln \left(\frac{X_{\mathrm{An}}^{\mathrm{pl}}}{X_{\mathrm{CaO}}^{\mathrm{liq}}\left(X_{\mathrm{AlO}_{1.5}}^{\mathrm{Liq}}\right)^{2}+\left(X_{\mathrm{SiO}_{2}}^{\mathrm{liq}}\right)^{2}}\right) \\
& -3.166\left(X_{\mathrm{CaO}}^{\mathrm{liq}}\right)-3.137\left(\frac{X_{\mathrm{AlO}_{1.5}}^{\mathrm{liq}_{1.5}}}{X_{\mathrm{AlO}_{1.5}}^{\mathrm{liq}}+X_{\mathrm{SiO}_{2}}^{\mathrm{liq}}}\right) \\
& +1.216\left(X_{\mathrm{Ab}}^{\mathrm{pl}}\right)^{2}-2.475 \times 10^{-2} \\
& \left(P(\mathrm{kbar})+0.2166\left(\mathrm{H}_{2} \mathrm{O}^{\mathrm{liq}}\right)\right)
\end{aligned}
$$

Here, $\quad X_{\mathrm{An}}^{\mathrm{pl}}=X_{\mathrm{CaO}}^{\mathrm{pl}} /\left(X_{\mathrm{CaO}}^{\mathrm{pl}}+X_{\mathrm{NaO}_{0.5}}^{\mathrm{pl}}+X_{\mathrm{KO}_{0.5}}^{\mathrm{pl}}\right) \quad$ and $X_{\mathrm{Ab}}^{\mathrm{pl}}=X_{\mathrm{NaO}_{0.5}}^{\mathrm{pl}} /\left(X_{\mathrm{CaO}}^{\mathrm{pl}}+X_{\mathrm{NaO}_{0.5}}^{\mathrm{pl}}+X_{\mathrm{KO}_{0.5}}^{\mathrm{pl}}\right)$, where mineral components are calculated as cation fractions; all liquid components except $\mathrm{H}_{2} \mathrm{O}$ are cation fractions, calculate on an anhydrous basis without renormalization of weight percent values; $\mathrm{H}_{2} \mathrm{O}$ is the wt $\%$ in the liquid phase.

$$
\begin{aligned}
& \mathrm{P}(\text { kbar })=-42.2+4.94 \times 10^{-2} \mathrm{~T}(\mathrm{~K})+1.16 \times 10^{-2} \\
& \mathrm{~T}(\mathrm{~K}) \ln \left(\frac{X_{\mathrm{AlO}_{1.5}}^{\mathrm{liq}} X_{\mathrm{Ab}}^{\mathrm{pl}} X_{\mathrm{CaO}}^{\mathrm{liq}}}{X_{\mathrm{An}}^{\mathrm{pl}} X_{\mathrm{NaO}_{0.5}}^{\mathrm{liq}} X_{\mathrm{SiO}_{2}}^{\mathrm{liq}}}\right)-382.3\left(X_{\mathrm{SiO}_{2}}^{\mathrm{liq}}\right)^{2} \\
& +514.2\left(X_{\mathrm{SiO}_{2}}^{\operatorname{liq}}\right)^{3}-19.6 \ln \left(X_{\mathrm{Ab}}^{\mathrm{pl}}\right)-139.8\left(X_{\mathrm{CaO}}^{\mathrm{liq}}\right) \\
& +287.2\left(X_{\mathrm{NaO}_{0.5}}^{\mathrm{liq}}\right)+163.9\left(X_{\mathrm{KO}_{0.5}}^{\mathrm{liq}}\right)
\end{aligned}
$$

For clinopyroxene-liquid barometry, the Eq. (A3) which is presented by Putirka (2008) was used.

$$
\begin{aligned}
& \mathrm{P}(\text { Kbar })=-57.9+0.0475 \mathrm{~T}(\mathrm{~K})-40.6\left(X_{\mathrm{FeO}}^{\mathrm{liq}}\right) \\
& -47.7\left(X_{\mathrm{CaTs}}^{\mathrm{cpx}}\right)+0.676\left(\mathrm{H}_{2} \mathrm{O}^{\mathrm{liq}}\right)-153\left(X_{\mathrm{CaO}_{0.5}}^{\mathrm{liq}} X_{\mathrm{SiO}_{2}}^{\mathrm{liq}}\right) \\
& +6.89\left(\frac{X_{\mathrm{Al}}^{\mathrm{cpx}}}{X_{\mathrm{AlO}_{0.5}}^{\mathrm{liq}}}\right)
\end{aligned}
$$

Here, the last term represents the ratio of the total number of $\mathrm{Al}$ in clinopyroxene when calculated on a 6 oxygen basis $\left(X_{\mathrm{Al}}^{\mathrm{cpx}}=X_{\mathrm{Al}}^{\mathrm{cpx}}+X_{\mathrm{Al}}^{\mathrm{Cpx}}\right.$ (VI) $)$ and the cation fraction of $\mathrm{Al}$ in liquid. 
Acknowledgements. We are most grateful to the staff of Centre for Experimental, Mineralogy, Petrology and Geochemistry (CEMPEG), Uppsala University, Sweden, especially Dr. Jaroslaw Majka and Dr. Abigail Barker for valuable help during microprobe analyses and Lisa Samrock for help with manuscript preparation. Financial support for this work was provided by the Ministry of Science and Technology of Iran, with complementary support through Uppsala University and the Swedish Science Foundation.

Edited by: F. Rossetti

\section{References}

Agard, P., Omrani, J., Jolivet, L., and Mouthereau, F.: Convergence history across Zagros (Iran): Constraints from collisional and earlier deformation, Int. J. Earth. Sci., 94, 401-419, 2005.

Agard, P., Omrani, J., Jolivet, L., Whitechurch, H., Vrielynck, B., Spakman, W., Monie, P., Meyer, B., and Wortel, R.: Zagros orogeny: a subduction-dominated process, Geol. Mag., 148, 692-725, 2011.

Allegre, C. J., Provost, A., and Jaupart, C.: Oscillatory zoning: a pathological case of crystal growth, Nature, 294, 223-228, 1981.

Andrews, B. J., Gardner, J. E., and Housh, T. B.: Repeated recharge, assimilation, and hybridization in magmas erupted from El Chichón as recorded by plagioclase and amphibole phenocrysts, J. Volcanol. Geoth. Res., 175, 415-426, 2008.

Annen, C., Blundy, J. D., and Sparks, R. S. J.: The genesis of intermediate and silicic magmas in deep crustal hot zones, J. Petrol., 47, 505-539, 2006.

Arvin, M. and Robinson, P. T.: The petrogenesis and tectonic setting of lava from Baft ophiolitic melange, SW Kerman, Iran, Can. J. Earth Sci., 31, 824-834, 1994.

Azizi, H. and Moinevaziri, H.: Review for tectonic setting for Cretaceous to Quaternary volcanism in NW Iran, J. Geodyn., 47, 167-179, 2009.

Babazadeh, S. A and De Wever, P.: Early Cretaceous radiolarian assemblages from radiolarites in the Sistan Suture (eastern Iran), Geodiversitas, 26, 185-206, 2004.

Baroz, J., Macaudière, J., Montigny, R., Noghreyan, M., Ohnen stetter, M., and Rocci, G. A.: Ophiolites and related formations in the central part of the Sabzevar (Iran) and possible geotectonic reconstructions, Geodynamic Project (Geotraverse) in Iran: GSI, Report no. 51, 51-68, 1983.

Behrens, H. and Gaillard, F.: Geochemical aspects of melts: volatiles and redox behavior, Elements, 2, 275-280, 2006.

Berberian, F. and Berberian, M.: Tectono-plutonic episodes in Iran, in Zagros, Hindu Kush, Himalaya: Geodynamic Evolution, Geodynamics, 3, 5-32, 1981.

Berberian, F., Muir, I. D., Pankhurst, R. J., and Berberian, M.: Late Cretaceous and early Miocene Andean type plutonic activity in northern Makran and central Iran, J. Geol. Soc. London, 139, 605-614, 1982.

Berberian, M. and King, G.C.P.: Towards a paleogeography and tectonic evolution of Iran, Can. J. Earth Sci., 18, 210-265, 1981.

Bina, M. M., I. Bucur, I., Pervot, M., Meyerfeld, Y., Daly, L., Cantagrel, J. M., and Mergoil, J.: Palaeomagnetism petrology and geochronology of Tertiary magmatic and sedimentary units from Iran, Tectonophysics, 121, 303-329, 1986.
Blundy, J. D. and Holland T. J. B.: Calcic amphibole equilibria and a new amphiboleplagioclase geothermometer, Contrib. Mineral. Petr., 104, 208-224, 1990.

Bottinga, Y. Kudo, A., and Weill, D.: Some observation on oscillatory zoning and crystallization of magmatic plagioclase, Am. Mineral., 51, 792-806, 1966.

Castillo, P. R.: An overview of adakite petrogenesis, Chinese Sci. Bull., 51, 257-268, 2006.

Castillo, P. R.: Adakite petrogenesis., Lithos, 134, 304-316, 2012.

Chang, Z. and Meinert, L. D.: The magmatic-hydrothermal transition- evidence from quartz phenocryst textures and endoskarn abundance in $\mathrm{Cu}-\mathrm{Zn}$ skarns at the Empire Mine, Idaho, USA. Chem. Geol., 210, 149-171, 2004.

Chaussard, E. and Amelung, F.: Regional controls on magma ascent and storage in volcanic Arcs, Geochem. Geophys. Geosyst., 1407-1418, 2014.

Chiaradia, M., Müntener, O., Beate, B., and Fontignie, D.: Adakitelike volcanism of Ecuador: lower crust magmatic evolution and recycling, Contrib. Mineral. Petr., 158, 563-588, 2009.

Danyushevsky, L. V., Falloon, T. J., Crawford, A. J., Tetroeva, S. A., Leslie, R. L., and Verbeeten, A.: High-Mg adakites from Kadavu Island Group, Fiji, southwest Pacific: evidence for the mantle origin of adakite parental melts, Geology, 36, 499-502, 2008.

Davidson, J., Turner, S., Handley, H., Mcpherson, C., and Dosseto, A.: Amphibole "sponge" in arc crust?, Geology, 35, 787-790, 2007.

Deer, W. A., Howie, R. A., and Sussman, J. Z.: An introduction to rock- forming minerals, Longman Ltd, 528 pp., 1986.

Defant, M. J. and Drummond, M. S.: Derivation of some modern arc magmas by melting of young subducted lithosphere, Nature, 347, 662-665, 1990.

Donaldson, C. H. and Henderson, C. M. B.: A new interpretation of round embayments quartz crystals, Mineral. Mag., 52, 27-33, 1988.

Foley, F., Norman, J., Pearson, N. J., Rushmer, T., Turner, S., and Adam, J.: Magmatic evolution and magma mixing of Quaternary adakites at Solander and little Solander Islands, New Zealand, J. Petrol., 54, 1-42, 2013.

Garcia, M. O. and Jacobson, S. S.: Crystal clots, amphibole fractionation and the evolution of calc-alkaline magmas, Contrib. Mineral. Petrol., 69, 319-327, 1979.

Ghasemi, H., Sadeghian, M., Khanalizadeh, A., and Tanha, A.: Petrography, geochemistry and radiometric ages of high-silica adakitic domes of Neogene continental arc, South of Quchan, Iranian J. Crystal. Mineral., 3, 347-370, 2010.

Ghasemi, H., Barahmand, M., and Sadeghian, M.: The Oligocene basaltic lavas of east and southeast of Shahroud: Implication for back-arc basin setting of Central Iran Oligo-Miocene basin, Petrol. J., 2, 77-94, 2011 (in Persian).

Gill, J. B.: Orogenic andesites and plate tectonics. Springer, New York, Springer-Verlag, 390 pp., 1981.

Ginibre, C., Gerhard Wörner, G., and Kronz, A.: Minor- and traceelement zoning in plagioclase: implications for magma chamber processes at Parinacota volcano, northern Chile, Contrib. Mineral. Petrol., 143, 300-315, 2002.

Guan, Q., Zhu, D. C., Zhao, Z. D., Zhang, L. L., Liu, M., Li, X. W., Yu, F., Liu, M. H., and Mo, X. X.: Late Cretaceous adakites from the eastern segment of the Gangdese Belt, Southern Tibet: prod- 
ucts of Neo-Tethyan mid-ocean ridge subduction, Acta Petrol. Sin., 26, 2165-2179, 2010 (in Chinese with English abstract).

Guo, F., Nakamuru, E., Fan, W., Kobayoshi, K., and Li, C.: Generation of Paleocene adakitic andesites by magma mixing: Yanji area, NE China, J. Petrol., 48, 661-692, 2007.

Holland T. J. B. and Blundy, J. D.: Non-ideal interactions in calcic amphiboles and their bearing on amphibole-plagioclase thermometry, Contrib. Mineral. Petrol., 116, 433-447, 1994.

Houseman, G. A., McKenzie, D. P., and Molnar, P. J.: Convective instability of a thickened boundary layer and its relevance for the thermal evolution of continental convergent belts, J. Geophys. Res., 86, 6115-6132, 1981.

Housh, T. B. and Luhr, J. F.:Plagioclase-melt equilibria in hydrous system, Am. Mineral., 76, 477-492, 1991.

Humphreys, M. C. S., Blundy, J. D., and Sparks, R. S. J.: Magma evolution and open-system processes at Shiveluch volcano: insights from phenocrysts zoning, J. Petrol., 47, 2303-2334, 2006.

Humphreys, M. C. S., Christopher, T., and Hards, V.: Microlite transfer by disaggregation of mafic inclusions following magma mixing at Soufrie're Hills volcano, Montserrat, Contrib. Mineral. Petrol., 157, 609-624, 2009.

Irvine, T. N. and Baragar, W. R. A.: A guide to the chemical classification of the common volcanic rocks, Can. J. Earth Sci., 8, 523-548, 1971

Jahangiri, A.: Post-collisional Miocene adakitic volcanism in NW Iran: Geochemical and geodynamic implications, J. Asian Earth Sci., 30, 433-447, 2007.

Jamshidi, K., Ghasemi, H., and Sadeghian, M.: Petrology and geochemistry of the Sabzevar post-ophiolitic high silica adakitic rocks, J. Petrol., 5, 51-68, 2014 (in Persian).

Keskin, M., Pearce, J. A., and Mitchell, J. G.: Volcano-stratigraphy and geochemistry of collision-related volcanism on the ErzurumKars Plateau, North Eastern Turkey, J. Volcanol. Geoth. Res., 85, 355-404, 1998.

Khalatbari Jafari, M., Babaie, H. A., and Gani, M.: Geochemical evidence for Late Cretaceous marginal arc-to-back arc transition in the Sabzevar ophiolitic extrusive sequence, northeast Iran, J. Asian Earth Sci., 70, 209-230, 2013.

Kohn, M. J. and Parkinson, C. D.: Petrologic case for Eocene slab break off during the Indo-Asian collision, Geology, 30, 591-594, 2002.

Le Bas, M. J., Le Maitre, R. W., Streckeisen, A., and Zanettin, B.: A chemical classification of volcanic rocks based on the total alkali-silica diagram, J. Petrol., 27, 745-750, 1986.

Leake, B. E.: Nomenclature of amphiboles. Am. Mineral., 63, 1023-1052, 1978.

Leake, B. E., Woolley, A. R., Arps, C. E. S., Birch, W. D., Gilbert, M. C., Grice, J. D., Hawthorne, F. C., Kato, A., Kisch, H. J., Krivovichev, V. G., Linthout, K., Laird, J., Mandarino, J. A., Maresch, W. V., Nickel, E. H., Rock, N. M. S., Schumacher, J. C., Smith, D. C., Stephenson, N. C. N., Ungaretti, L., Whittaker, E. J. W., and Youzhi, G.: Nomenclature of amphiboles: Report of the Subcommittee on Amphiboles of the International Mineralogical Association, Commission on New Minerals and Mineral Names, Am. Mineral., 82, 1019-1037, 1997.

Leake, B. E., Wooley, A. R., Birch, W. D., Burke, E. A. J., Ferraris, G, Grice, J. D., Hawthorne, F. C., Kisch, H. J., Krivovichev, V. G., Schumacher, J. C., Stephenson, N. C. N., and Whittaker, E. J. W.: Nomenclature of amphiboles: Additions and revisions to the International Mineralogical Associations amphibole nomenclature, Am. Mineral., 89, 883-887, 2004.

Le Maitre, R. W.: Some Problems of the Projection of Chemical Data into Mineralogical Classifications, Contrib. Mineral. Petrol., 56, 181-189, 1976.

Lensch, G.: Major element geochemistry of the ophiolites in northeastern Iran, in: "Ophiolites, Proceedings Intern. Ophiolite Symposium, Cyprus 1979”, edited by: Panayotou, A., Geological Survey Department, Cyprus, 398-401, 1980.

Lensch, G., Mihn, A., and Alavi-Tehrani, N.: Petrography and geology of the ophiolite belt north of Sabzevar/ Khorasan (Iran), Neues Jahrb. Geol. P-M., 131, 156-178, 1977.

L'Heureux, I.: Oscillatory zoning in plagioclase: thermal effects, Physica A, 239, 137-146, 1997.

Majidi, J.: Sabzevar Geological Map and Report, 1:100 000. Geological Survey and Mining Exploration of Iran, 1999.

Maniar, P. D. and Piccoli, P. M.: Tectonic discrimination of granitoids. Geol. Soc. Am. Bull., 101, 635-643, 1989.

Martel, C., Pichavant, M., Holtz, F., Scaillet, B., Bourdier, J. L. and Traineau, H.: Effects of $f \mathrm{O}_{2}$ and $\mathrm{H}_{2} \mathrm{O}$ on andesite phase relation between 2 and 4 kbar, J. Geophys. Res., 104, 29453-29470, 1999.

Martin, H., Smithies, R. H., Rapp, R., Moyen, J. F., and Champion, D.: An overview of adakite, tonalite-trondhjemite-granodiorite (TTG), and sanukitoid: relationships and some implications for crustal Evolution, Lithos, 79, 1-24, 2005.

Mohamadi Gorchi, E., Ghorbani, G., and Shafaii Moghadam, H.: The Origin of high- $\mathrm{SiO}_{2}$ adakites in southwestern part of the Sabzevar ophiolites, 1st National Conferences on the Iranian Plateau Geology, 2013 (in Persian).

Motaghi, K., Tatar, M., Shomali, Z. H., Kaviani, K., and Priestley, K.: High resolution image of uppermost mantle beneath NE Iran continental collision zone, Phys. Earth Planet. In., 208, 38-49, 2012.

Müntener, O., Kelemen, P. B., and Grove, T. L.: The role of $\mathrm{H}_{2} \mathrm{O}$ during the crystallization of primitive arc magmas under uppermost mantle conditions and genesis of igneous pyroxenites: an experimental study, Contrib. Mineral. Petrol., 141, 643-658, 2001.

Murphy, J. B., Blais, S. A., Tubrett, M., McNeil, D., and Middleton, M.: Microchemistry of amphiboles near the roof of a mafic magma chamber: Insights into high level melt evolution, Lithos, 148, 162-175, 2012.

Noghreyan, M. K.: Evolution geochimique, mineralogique, et structurale d'un edifice ophiolitique singulier: Le massif de Sabzevar (Partie Central), NE d'Iran. These Sci, Univ. de Nancy I, France, 239 pp., 1982.

O'Neill, H. S. C. and Pownceby, M. L.: Thermodynamic data from redox reactions at high temperatures, I. An experimental and theoretical assessment of the electrochemical method using stabilized zirconia electrolytes, with revised values for the Fe-"FeO", $\mathrm{Co}-\mathrm{CoO}, \mathrm{Ni}-\mathrm{NiO}$, and $\mathrm{Cu}-\mathrm{Cu}_{2} \mathrm{O}$ oxygen buffers, and new data for the W-WO $\mathrm{W}_{2}$ buffer, Contrib. Mineral. Petrol., 114, 296-314, 1993.

Pearce, T. H. and Kolisnik, A. M.: Observations of plagioclase zoning using interference imaging, Earth-Sci. Rev., 29, 9-26, 1990.

Petford, N. and Atherton, M.: Na-rich partial melts from newly underplated basaltic crust: the Cordillera Blanca Batholith, Peru, J. Petrol., 37, 1491-1521, 1996. 
Putirka, K. D.: Thermometers and barometers for volcanic systems, in: Minerals, inclusions and volcanic processes, edited by: Putrika, K. and Tepley, F., Rev. Mineral. Geochem., 69, 61-120, 2008.

Putirka, K. D., Mikaelian, Ryerson, H., F., and Shaw, H.: New clinopyroxene-liquid thermobarometers for mafic, evolved, and volatile-bearing lava compositions, with applications to lavas from Tibet and the Snake River Plain, Idaho, Am. Mineral., 88, 1542-1554, 2003.

Ramos, F. C., Wolff, J. A., and Tollstrup, D. L.: Sr isotope disequilibrium in Columbia River flood basalts: evidences for rapid shallow-level open-system processes, Geology, 33, 457-460, 2005.

Reilinger, R., McClusky, S., Vernant, P., Lawrence, S., Semih Ergintav, S., Cakmak, R., Haluk Ozener, H., Kadirov, F., Guliev, I., Stepanyan, R., Nadariya, M., Hahubia, G., Mahmoud, S., Sakr, K., ArRajehi, A., Paradissis, D., Al-Aydrus, A., Prilepin, M., Guseva, T., Evren, E., Dmitrotsa, A., Filikov, S. V., Gomez, F., Riad Al-Ghazzi, R., and Karam, G.: GPS constraints on continental deformation in the Africa-Arabia-Eurasia continental collision zone and implications for the dynamics of plate interactions, J. Geophys. Res., 111, B05411, doi:10.1029/2005JB004051, 2006.

Ridolfi, F. and Renzulli, A.: Calcic amphiboles in calc-alkaline and alkaline magmas: thermobarometric and chemometric empirical equations valid up to $1130{ }^{\circ} \mathrm{C}$ and $2.2 \mathrm{GPa}$, Contrib. Mineral. Petrol., 163, 877-895, 2012.

Ridolfi, F., Renzulli, A., and Puerini, M.: Stability and chemical equilibrium of amphibole in calc-alkaline magmas: an overview, new thermobarometric formulations and application to subduction-related volcanoes, Contrib. Mineral. Petrol., 160, 4566, 2010.

Rooney, T. O., Franceschi, P., and Hall, C. M.: Water-saturated magmas in the Panama Canal region: a precursor to adakitelike magma generation, Contrib. Mineral. Petrol., 161, 373-388, 2010.

Rossetti, F., Nasrabady, M., Vignaroli, G., Theye, T., Gerdes, A., Razavi, S. M. H., and Moin Vaziri, H.: Early Cretaceous migmatitic mafic granulites from the Sabzevar range (NE Iran): Implications for the closure of the Mesozoic peri-Tethyan oceans in central Iran, Terra Nova, 22, 26-34, 2010.

Rossetti, F., Nasrabady, M., Theye, T., Gerdes, A., Monié, P., Lucci, F., and Vignaroli, G.: Adakite differentiation and emplacement in a subduction channel: The late Paleocene Sabzevar magmatism (NE Iran), Geol. Soc .Am. Bull. 126, 317-343, 2014.

Peccerillo, R. and Taylor, S. R.: Geochemistry of Eocene calcalkaline volcanic rocks from the Kastamonu area, northern Turkey, Contrib. Mineral. Petrol., 58, 63-81, 1976.

Salehinejad, H.: Petrological and geochemical investigation of subvolcanic domes of Bashtin area (SW of Sabzevar), MSc thesis, Shahrood University of Technology, Shahrood, Iran, 2008 (in Persian).

Shabanian, E., Acocella, V., Gioncada, A., Ghasemi, H. and Bellier, O.: Structural control on volcanism in intraplate post collisional settings: Late Cenozoic to Quaternary examples of Iran and Eastern Turkey. Tectonics, 31, 3013-3042, 2012.

Shafaii Moghadam, H. S., Whitechurch, H., Rahgoshay, M., and Monsef, I.: Significance of Nain-Baft ophiolitic belt (Iran): Short-lived, transtensional Cretaceous back-arc oceanic basins over the Tethyan subduction zone, C. R. Geosci., 341, 10161028, 2009.

Shafaii Moghadam, S. H., Zaki Khedr, M., Arai, S., Stern, R. J., Ghorbani, G., Tamura, A., and Ottley, C.: Arc-related harzburgite-dunite-chromitite complexes in the mantle section of the Sabzevar ophiolite, Iran: a model for formation of podiform chromitites, Gondwana Res., 27, 575-593, doi:10.1016/j.gr.2013.09.007, 2015.

Shojaat, B., Hassanipak, A. A., Mobasher, K., and Ghazi, A. M.: Petrology, geochemistry and tectonics of the Sabzevar ophiolite, North Center Iran, J. Asian Earth Sci., 21, 1053-1067, 2003.

Sisson, T. W. and Grove, T. L.: Experimental investigations of the role of $\mathrm{H}_{2} \mathrm{O}$ in calc-alkaline differentiation and subduction zone magmatism. Contrib. Mineral. Petrol., 113, 143-166, 1993.

Slaby, E. and Götze, J.: Feldspar crystallization under magmamixing conditions shown by cathodoluminescence and geochemical modeling- a case study from the Karkonosze pluton (SW Poland), Mineral. Mag., 68, 561-577, 2004.

Spies, O., Lensch, G., and Mihem, A.: Geochemistry of the postophiolitic Tertiary volcanics between Sabzevar and Quchan (NE Iran), GSI, Report no. 51, 247-266, 1983.

Stampfli, G. M. and Borel, G. D.: A plate tectonic model for the Paleozoic and Mesozoic constrained by dynamic plate boundaries and restored synthetic oceanic isochrones, Earth Planet. Sc. Lett., 196, 17-33, 2002.

Stewart, D. C.: Crystal clots in calc-alkaline andesites as breakdown products of high-Al amphiboles, Contrib. Mineral. Petrol., 53, 195-204, 1975.

Sun, S.S. and McDonough, W. F.: Chemical and isotopic systematics of oceanic of basalts: implication for mantle composition and processes, in: Magmatism in oceanic basins, edited by: Saunders, A. D. and Norry, M. J., Geol. Soc. London, 42, 313-345, 1989.

Tepley, F. J., Davidson, J., Tilling, R. I., and Arth, J. G.: Magma mixing, recharge and eruptive histories recorded in plagioclase phenocrysts from El Chichón Volcano, Mexico, J. Petrol., 41, 1397-1411, 2000.

Troll, V. R. and Schmincke, H.-U.: Magma mixing and crustal recycling recorded in ternary feldspar from compositionally zoned peralkaline ignimbrite "A", Gran Canaria, Canary Islands, J. Petrol., 43, 243-270, 2002.

Troll, V. R., Donaldson, C. H., and Emeleus, C. H.: Pre-eruptive magma mixing in ash-flow deposites of the Tertisry Rum Igneous Centre, Scotland, Contrib. Mineral. Petrol., 147, 722-739, 2004.

Turner, S., Arnaud, N., Liu, J., Rogers, N., Hawkesworth, C., Harris, N., Kelley, S., van Calsteren, P., and Deng, W.: Post-collisional, shoshonitic volcanism on the Tibetean plateau: implications for convective thinning of the lithosphere and the source of ocean island basalts, J. Petrol., 37, 45-71, 1996.

Wang, Q., Wyman, D. A., Xu, J.-F., Zhao, Z. H., Jian, P., Xiong, X. L., Bao, Z. W., Li, C. F., and Bai, Z. H.: Petrogenesis of Cretaceous adakitic and shoshonitic igneous rocks in the Luzong area, Anhui Province (Eastern China): implications for geodynamics and $\mathrm{Cu}-\mathrm{Au}$ mineralization, Lithos, 89, 424-446, 2006.

Wang, X. L., Shu, X. J., Xu, X., Tang, M., and Gaschnig, R.: Petrogenesis of the Early Cretaceous adakite-like porphyries and associated basaltic andesites in the eastern Jiangnan orogen, southern China, J. Asian Earth Sci., 61, 243-256, 2012. 